University of Rhode Island

DigitalCommons@URI

Open Access Master's Theses

1976

\title{
Essentialism and Effluvia 1700-1740: A Thematic Study
}

Robert E. Barietta

University of Rhode Island

Follow this and additional works at: https://digitalcommons.uri.edu/theses

\section{Recommended Citation}

Barietta, Robert E., "Essentialism and Effluvia 1700-1740: A Thematic Study" (1976). Open Access

Master's Theses. Paper 1556.

https://digitalcommons.uri.edu/theses/1556

This Thesis is brought to you for free and open access by DigitalCommons@URI. It has been accepted for inclusion in Open Access Master's Theses by an authorized administrator of DigitalCommons@URI. For more information, please contact digitalcommons-group@uri.edu. 


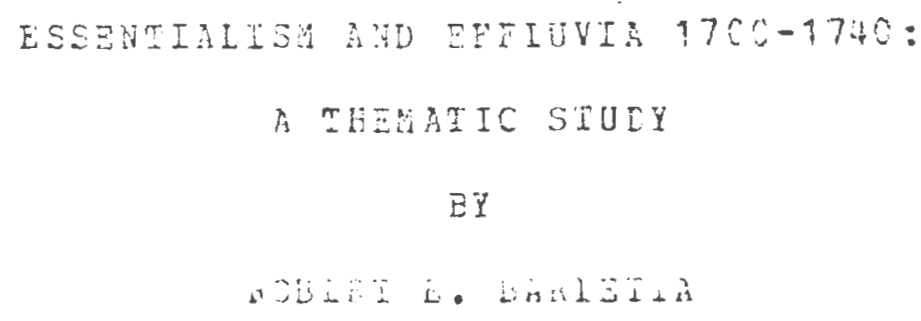

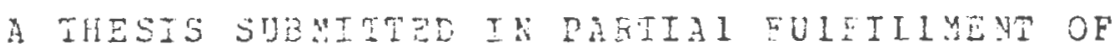
FEQULOEHEYTE FOE TUF IEGEFE CE

$$
\text { MISTES CF ARTS }
$$

IN

IISTCMI

UNTVESSTYY OE PYODE ISLAOD

1978 


\section{Atstract}

There heve bers naryexplaraticrs cefered for the transformaticr which cocersed in ratural rhilosopiny during the sixteenth and severteenth certuries. che such explaraticn bu: that this "sciertific revoluticr" bas Fhilcsophical. i.e. the chances which cccurred in ratural phijcsckly tere warked ty the trarejtion frcu an essentialiet to a nor-esertialjet viek cf nature. The validity ce tris exfaraticr was inbetiquted by selecting an essertiajist theme, Effluvial trecry, and teacira its develcrment from its orique ir fercissance ccoult Fhilcsophy ic the inccrporation ct effluvia intc the Fhysical thcolp ci the 17th ard 1Eth certury ratural chilcscrby. This has accorflished ry lee cf the thematic analysis as de

Fom tris analysis. it was ccrcluced that effluvial

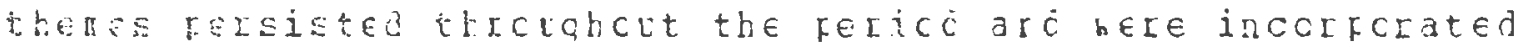

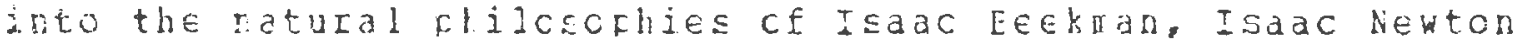

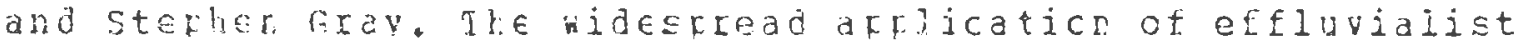
thenes $b y$ ren of: such differing views cf rature led to the Lejection os the profosal that the pcst-revcluticnary fericd conja Le crezactezized as rofoessertialist. Finally, with reqaid to the rissere of the effluvialist theme in the work cf Grav. it was toung that the electrical effluviug was the

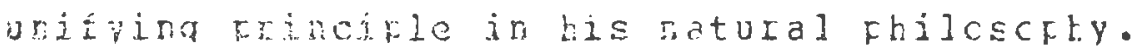


Acknowlejqements

I would like to thant ercesesor J. M. Eriqus for ail his helf ard quidance in the pursuit of this researci problen. I would also like to thark Erciessor G. Silvastri. for his advice in the preparation of this thesis. Finally, I would like to thank ny Hite, Liane, ter ber patience and encouraqen $=n \pm$. 
To tiane 
CCATENTS

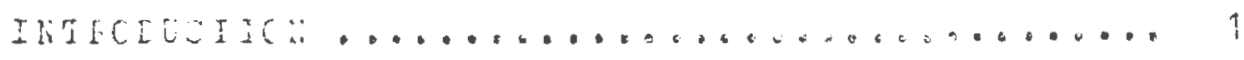

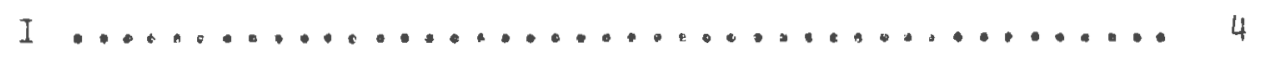

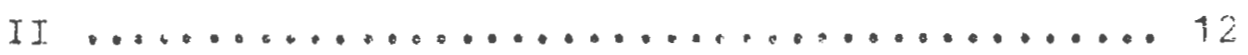

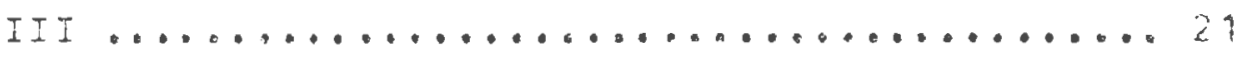

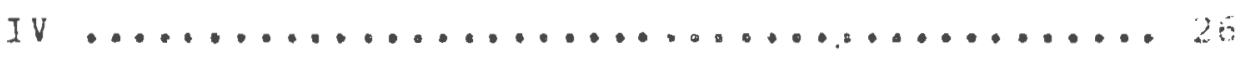

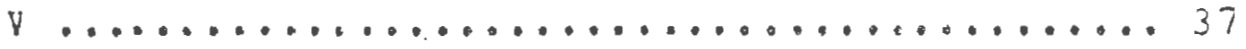

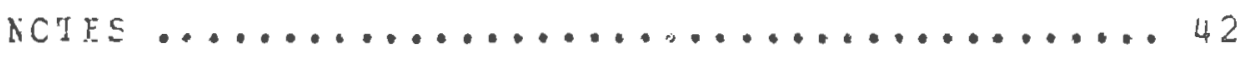

APEENDIX I ......................... 48

SELECIEL EIEIICEEAEHY .................. 51 


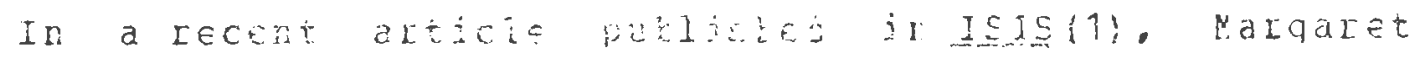
Csler discusses the rede ct Galidec jn tretransiticn from medieval tc reatl science in torns ef a shift in the epistemolcaical basis cf science. ris is shift from essentialism to noressentialis. ere sas, is "a chazacteristic feature ct scierce durire tre sciertific

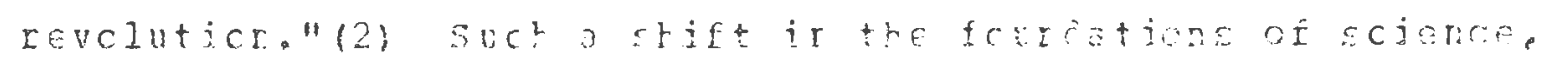
if it ir fact ccouré, bold irdeed be ievoluticnary, and would be suquestive ce a large scaie razadiciatic charue cccurrira in the 1eth ard 17 th certurjes. certainly. the roticn of a siarf trangiticn betiegr tedievai ratural Fhilcscrhy, bich cealt itt the raitie cr esserces ce thinas, tc acoer science, bhich claje te doal caly in phercaena, is eprealina if crly for jt: siplicity. To te sure, HS. Osler pcints cut that licressertialist viens of science preceded the scientific revcluticr. The tricst ct her arquirent, lowever, is that fre-revcliticrary scierce was essertialist, and fCst-revcluticnary science iras nct. Galilec, as a $a c i s n t i s t$ ir. the aidst ce relcluticn, refiects the transitice betheer ejistenciccies ir his fersoral scientific deviclenent.

To evaluce the validity cf this arcunent, cre ust first corsider the ICIS cferjsterclcob in the metbcaclcqy of science. certairly, with reqard tc the individual sciertist, cuesticrs ci bhat constitutes knowledqe will linit and aires lis researches. Ir this respect, the matter cE calilec's essentialist attituces serves as a qcod 
EACE 2

exampe. It is quibe zeascrebs ic assume that at essentialist weild have beer ictally urcercerned with tha equaticns describira the traiectcries ci railing rojies. Thus, insctar as cajizec was ccrcerred bith kinematics, he has tehavina as a ncnesscutialist, Hut, ribever motivates the individual investicatcr is, tc a certain ertent

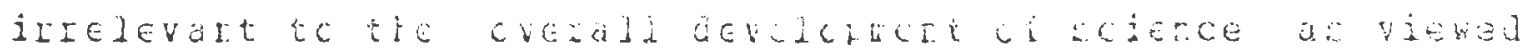
in the contincert rlale cf fhercieric and analytic concefts. (4) Eublic scierce is corcerned urimarily with these the tyfes of profcsiticrs, ard, this, comanication

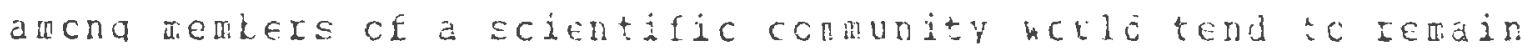
or trje rlare. Irje is ret to cest the importarce ci philcscohic, aestretic, sccjclogical ci. psycholcaical ccnsideraticis in examining tlie develcfuert cf science. To be sure, theyare ce qreat iafcrtarce. Ile infut ci such consideratiors in scientific osvelcrert is not rerally reqardec as a fart cf "scientific ircuirl by scientists themselves. This fact helrs tc accort fcr the somenhat dry nature cf scientitic prose.

It is infertant tc reccerize tre tact that ucst ccururicaticn among scientists cccurs ujtrin this rather naricw range of the "sciertieic", Rct-scientific, or

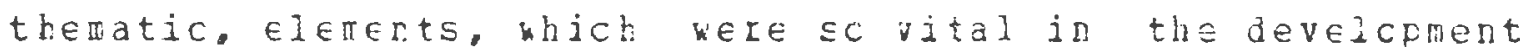
cf the scientific ideas in the first place are vsually caitted hen the scientist relays these iojes to his feers.

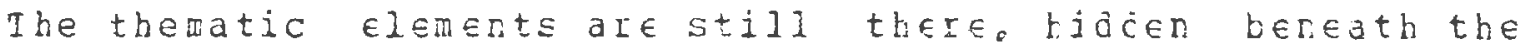


jacacr. Sirce thenatic attituer ale not directly transferrea, it is urise to inter that the eristemoloq of a sciontist is recesearily shared by tre brole sciertific ccarurity. (5)

Yet, fuhn(e) corgectly fcirts cut that the vary success cf a certain aficacl to scierce festers iurther Iesearch

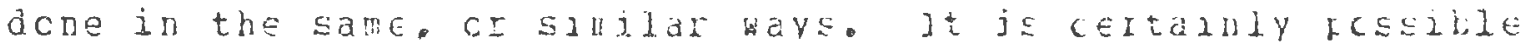

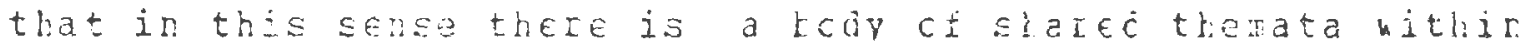
a sciertific conurity. Ir eact, these thenata helf detine the arcur. suct stared freccreefticrs ats aralogcus to Kuhn's faradian and houd be trarsitted ir wuch the sare ranner. che niaht conterid that efistencjcoies can be sharea therata, ard the shift frca essertials to nonessertialism is aralcacus to a charge in faracign. In cruez to frcve this conterticr, lichever, it kcula re necessarb to exauine the post-revcluticrary fericd tc see if itcould realiy $k$ characterized as ncnessentialist. This is rct an easy task, since, as was menticned earlier, tbefota are not lsually evidert ir. fuklic science. Eut as fcltcr foints cut, "the therlatic corfonent is acst chvicls bhen a science is ycunq" $(7)$, sc that an investicaticr intc scie newer aspects cefostrevclutionary scierce uicrt reveal the episterclcaical freccrcefticns ce the irvestiqatcrs. The following study of electrical thecries in the eiqhteenth century is icst such an irvestiqatior. 
The criqine of the idens alcut vissles añ effluvia ir

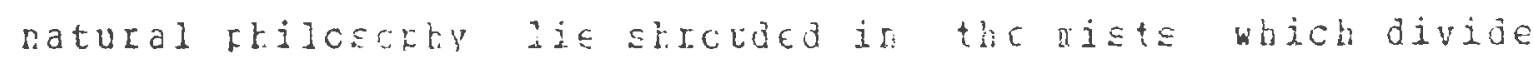
maic aro scierce. It arfeers they aIose trom an asfect of

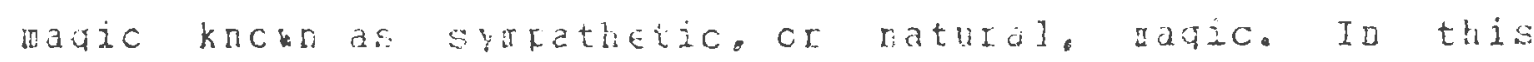

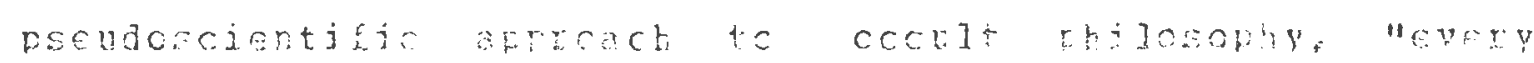
cbject in the wird was full cif cicuit syarathies."(1)

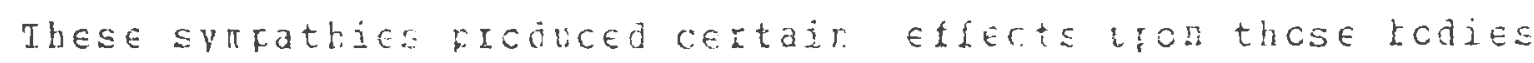
linkira trea to ratticlal fokers toud ir the celestial swhere. These sibathies here thelsuitted fror the celestial world by anan of efiluvia continually fouring

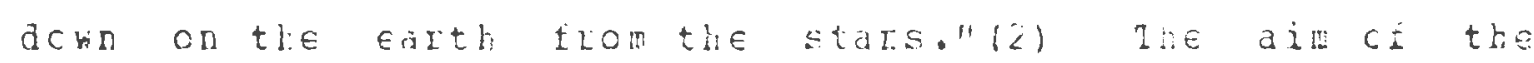
natural maqicion, then, was to clarrel ci direct tbese influences tc accouplish his erds.

Ihis arficact to the cccil fires jte best knowr exfessicr in the Asclefils, an agcrycis work dating tetween loo aro 300 A. E. Withjr the reiretic tradition, tris werk servea as the basis fcr acs of the aaqical literature of the riade aqes ard the fenaissance. It was wideiv relievea durinc the rellajsesce trat the Asclepius and, indeed, the whele cf the CcIflisereficus cculd te traced tc the bagic cf the ancient foyftians. (3) The ragic

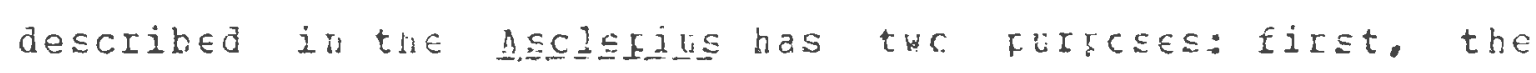
contrcl cf nature and second, fCI its herstip. Ecth these Ends kere accouplished by the sane reans so that, in practice, the $h \in[\in$ cne. ihe framencris cf syarathetjc magic 


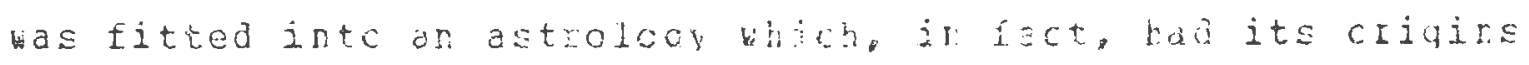
in Equptar cultug(4), ard this astroboj rrovided a basis for the urificatica cf all the varicus askects of the cccult sciences.

The influerco of fermetic iceas was cuite extensive ir. the Fenaissance. Thev are an intecrel fart ci tre philcsckbies cf ner such as Fici:c ard lice, and, aside frca their iafact cu heraissarce tracic ard rhiscsophy, haa a frofcuna effect or $\pi$ e ical arde as be stal see later. scientific thclibe. Fancis yates has traced the development and seread ce these ideas in heI kork Ejordanc Eruno and tre bernetic Iragitis sc there is no reed to do sc here. Ne. Yates cortericót thit cre ci the chief aqents for the disseminaticn of rer retjc ideas ir 16th century Eurcre was Gicidano Erunc, ard traced the sflead ci these ideasthIclat ria te Fralard, Frarce, and Geraray, as well as his rative Italy.

while it is fairly easy te descrite the influence of Hermetic ideas cf natural raqic and etfluvia cr metafhysics, it is rather difficult to discert thej influence ufon natural frilcscfhy. This is ajirly cie to the larqe theratic cerforent ct these ideas, fcr, as mertioned earlier, thearta aIe soldca stated exflicitly in a scientific mork lateant for fublic scrutiry. Cne kay of tracina this develcfment, hokever, is tc exerine the vse cef such terrs as effluvia arä virtues ir sciertific literature 
to see how theil conotatiors change cuer tine, and noting what characterigtics these concefts sest to gain or lose. To do this. it is necescacy to fcim a clear ruderstandina ce their use in crcult frilcschil. Ir the bertetic uriverse. all matter cr faIt has Jilhed tc fartictlai planets, stars, and corstellatjors therqb hich the raterial dorlo shared in the divine forces ci the uriverse. Ite qualities derived frcm the celestial realm bere called vitues, and their means ce transtission bele the efluvia. Eertainly. the philcsophy wich enfloved such ccrcefte is cssentialist. Ect it was the virtuss blich $\pi$ ade netter arrear as it aces. If one could contol cr charqe the virtues rresent in attor, be could charoe its esserce. Ihis aseurticn forfed the basis ce alchenical thecries cr the tearedition ce tase detals, ancna ctuer things. In fact, it was the tasic princible cr ratural ragic. rie raqiciar tcfed tc direct effluvia ir wavs cf ris cur chccsira ir crder te aclieve total fower cver the aaterial horld. Ey controliding the virtues fresert ir rcdies, he cculd exercise power over thcse tcdies. Chvicusly, such hcfes rere rever realized on such a qrand scale as the tctal ccrticl cf the universe. It is imfortant to reccqnize, howeyer, that the iimited contrcl and chantelirc cf ratcral fhercuta is a veI, real chject cf scientific activitv. This is rct meant to iufly an equivalence betweer. the scientist ard adus, but it is fcssible see farallels in the qcals tcrard which each 
strives.

Jchartes bepjer frovies a gocd ebarile ce the transiticr frca nadue tc sciertist. bis career reveals a man whos ideas seened to cecillate tetben nystical and nadical descifticus ce naturs cr the one hand, and statements of notural philoschp cr the cther. it woula seen that there was litt 1 e cr no aistirctjcr between the two

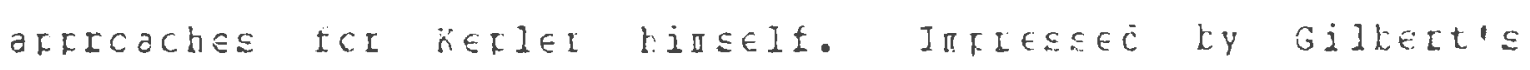
descrifticr: of the "virtues ce the raciet" (5), as well as bis identification ct the EaIth atu the raqnet, kefleI "exflained aravity, like gileert. as the action ce the Earth, which was a qreat wacnet, by aecrs of irdaterial raterial."(6) kerlex qCes leycre eilest. II his le iccertric uriverse, kefier attribltes the moticn cet the planets, described ty ris three laws cr riaretary moticr, to the force cf the maqnetic effluviua actiru uron tise flanets. Now, in keflor, the concept of heliocertricjty is asscciated with rystical rcticrs cf ecd's rresence in tile universe. sc that these raoretic efflivia retain their cccult connctation even when used to describe the fhysical wotion ce the Flanets.

Thrcuahcut the 17 th certury. Efflivial explanaticns cf natural frercuera arci ir. kreacth ard ccrflexity. Nicolo catec $(15 E E-1 \in E C)$ descrited the acticn cf the electrical effluvium ufcr matter ir. much tre saat way as kefler used the maqnetic effluviun. "He helc trat ficm electrum cr ary 


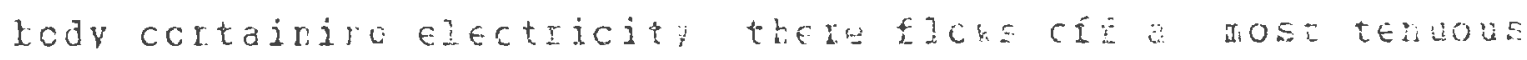
effluvium which is ditessed tircuar the air, but then returns to the electric rody arickeiros with it strasis ard ctrer raxticies that it erccurters."ij As effluvial explaraticrs ieccne ricre frevalent in ratural philcsophy. the cccult asfects of the effluvia dinirish in imfortance. Robert ecvle teljeved trat tre collisicr ci the raquetic effluvium with atcris eritted frch the sters bas the calse cf

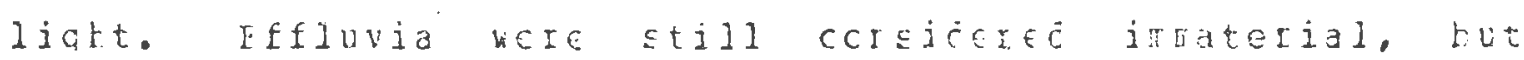
ratural frilcecrere began to treat trer ir auch the saa way as they dic atexial cifects.

lis Cartesian ratural frilcscrby lecane doninant in continental science, Effluvial exflaraticrs achiaved a retu jufcrtance. Isaac Ececkian (1570-16́3i). a frierd aro asscciate cf res cartes, useó a sircle eifluviun tc explain beat, aravity, ard a acietisa.

Eeeckuan accfted the byfct varied $s c m \in H l a t$ as time bert cr, cf a $v \in[y \in u b t] \in$ natteI, etler, air, sfirit, fierv farticles or celestial ccrfuscles ard effivija kich filled ard ariadted the kCILop and khich servec tc ExF]ain the frcbleas cf the vaculy, falidic bodies. and lianetic action. As he wicte in his Jcuiral cf 161E. 'It dces rct $\mathrm{L} \in \mathrm{st} \mathrm{cn}$ anytring but rasses withcut cistacle...'(9)

While Eefchnar's rcticn cf the ccrforeal nature cf this effluviur was mudded, he did siagest a rew froperty of 
effluvia。 In ajiticr to teirc the catse ch the raricus phercuera aertictea eabier, Eescyar considered this effluviua the cauce cécticr at a dietarce. Indeede the EEfluviul is tie esEtce cf sface itselt.

This sane idez was restated in a cartesian treatise on natural philoscohy fritter in loge ty a Jesuit, Eierre

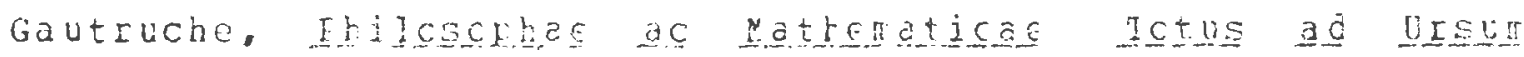

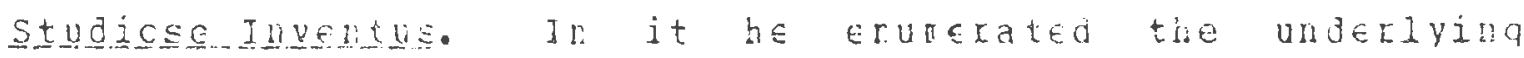
principles cef cartesian fhysics:

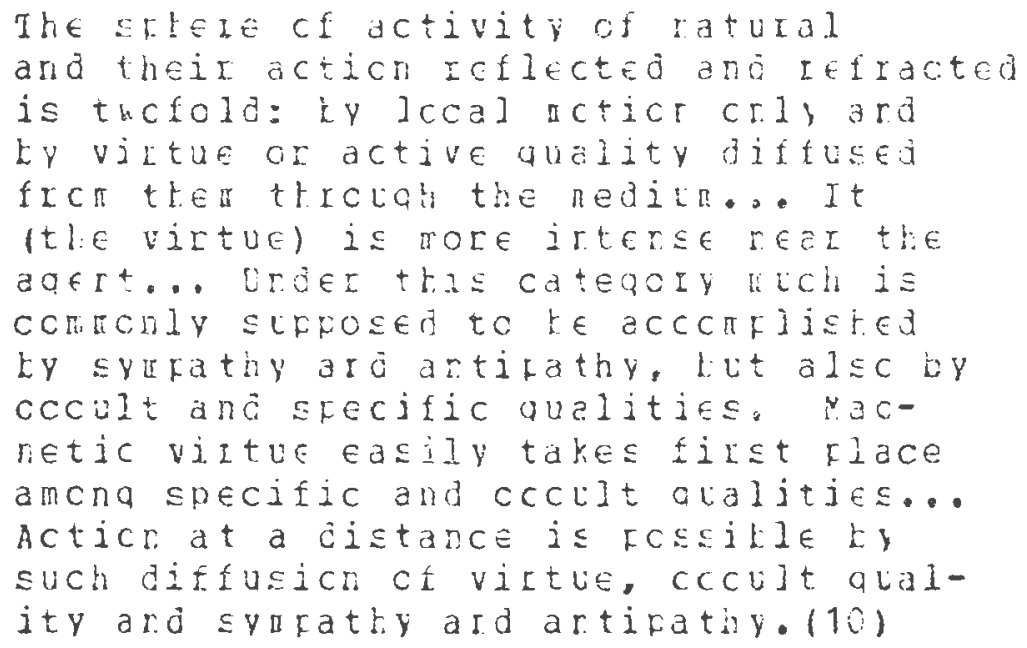

ic be sure, Gaveructe'seffluvja heIe ret as qeneral as Eeeckaan's, tut, thev accerlisted the same thing. serarately. each effluvium has resforsilie for criy a limited nutber cef fherorena. Lut tcoether they becale the princifle cf action in the uniyerse.

Gatrucres reticr of áry different effluvia was shared by ctker natural fhilcschers, tcth theoretical and 
experimental. Lu iabl spcke ct "liciocilic effluria,

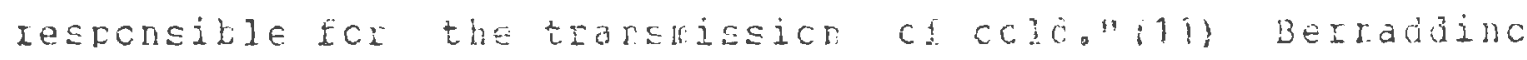
forraziri, jr 1691, azcrited varicus tarchetric charges to the acticr cf celestial effluvia. (1z) riber were electric and manetic effluvido as woll as effluvia rasponsitle foc liqht and heat. cne noted experinertalist, ctto von

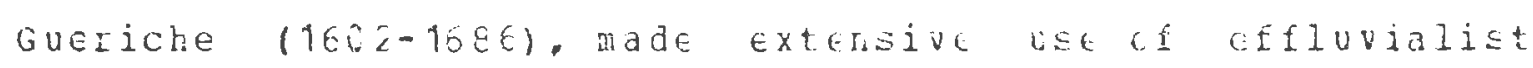

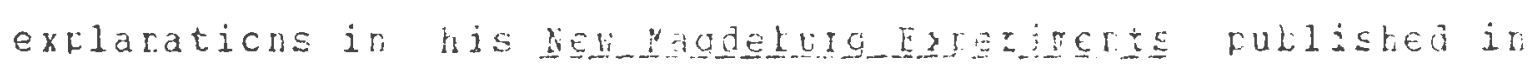
1672. ThCIndike Hrites:

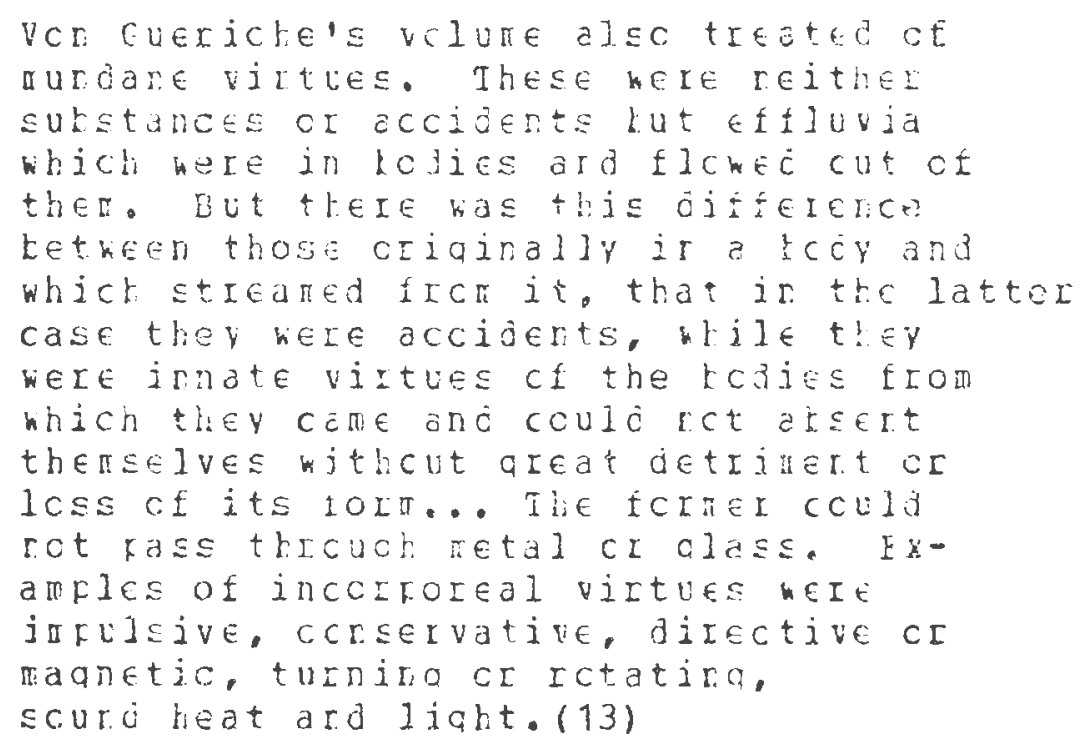

By row it rust be ctuicus that the rearincs cf virtue and effluvio tao cranceó ccneideratld fical the criqinal, nauical connctaticrs. Altbuah still essentialist in nature. effluvia are nch used tc describe the interactions amona kodies rather than the action of celestial and divine influences upcr murdane crjects. Cne carrct deny the cccult 
aspect ce these effluvia. Lut the entrabucalie confotation of their effects tas dirinisted if act vaished entirely. Ev the end ce the severteenth century, the efeluviur had taken its place teside the vertex es in accerted "scientific" Exharaticr ct ratural frefcefs.

These cartesiar iceas concering the rature of effiuria

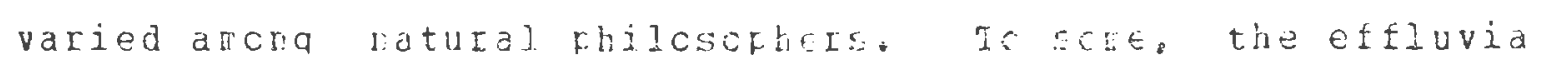
here dense ard material, while tc cthers tibl were imaterial. Jinge was a thirc crcur cé ratural

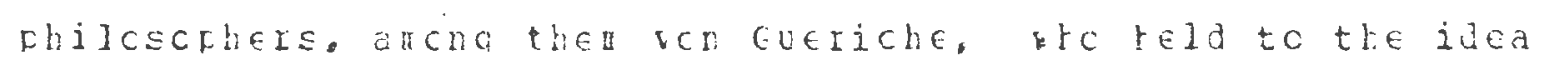
cf the existerce cf both tyfes cf cerzuia. Ihis lack cf precisicn ir tre aefiriticr cf a scientific concept is ty no liears unusual, Accordina to kutr, it is characteristic of a staqe ce scientific develcriert ir whicr raladicas are ctanainc cr a reb faradan is elleraira. If kuhn's afroach has ary validity, crê aust ccrcede that the 17th cortury is a critical ferica in the develcfent cf ratrai chilcsopry. and. therefore, it is act surfisina that the concepts that were beind articulated arinc tre fericd were vaque. Further, it shculd be referbasizeo trat concefts like effluvia bave a sticno the atic corcrert, and cne buld expect tre trenatic ejerert tc vary frca scientist to scientist. Wevertheless. the gereral rcticn of an effluviua was shared ty any natural plijoscrters ce the fericd desfite iffererces it the details cf afflicaticn ct tbe particular effluviru. 
I I

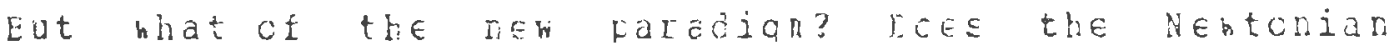
syntesis wict cocurs at the erd cetle ceatury iesclve these confictila ideas abcut effluyiz liesdy. Nentcris putished sciertitic kCIKs ccrtajn crly a te references to

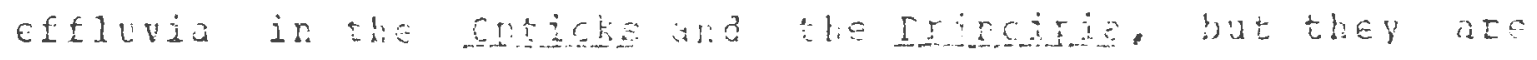
siarificart since t!e, ccrcerl the rieconcefticss ce Newtonian scierce. litural fhilcscptis as lewton conceivec it, as alite ajezerent frca that cf the cartosians. As kcvie pcirts cut, "Nehton's thcucht. rearly el oyo, hac beer.

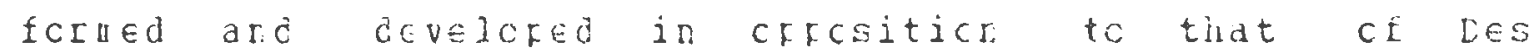
Cartes."(1) Tlis cfrcsiticr rot crly reints tomas disiailarities in the troughts of ths tho men, but, rcae infortantlv, zelares irfectiy to the cevelcfient cf tre concert cf eftluvia.

In ccrtrast tc later Cartesiar. ratural philcscfhers. Des cartes hiaself bcild allch uatter crly the quality of extersicn, and comfletel, excluded the ided cf any inhercrt oualies present in matter wich fulc account fcr its froperties (2). FCr les cartes the viverse was a flenum. Mcticn bas relative, and cocriced crly thrcigh the contact ce cre chject cn anctreI. Iris wcuid seem to exclude effluvia ercm cartesian science. Later cartesians, bchever, advanced the rction of efeluvia (ccrforeal ara inccrfcreal) as a tasis fcr certair fherodena, Esfecially those invclvina acticr at a cistance. 
Nentco Iejected viclently this rectaristic uriverse. Throughut the Expcjide he cisfutec tre cartesian clajis on ratheratical orcunes, insistina that the univarse hhich Les cartes uescrited coula ret be icertifiad hith the whysical wCIld. mete ftercaera that ke krow to exist sirfy could not be fIccucea by the caltesian rodel. As strcru as

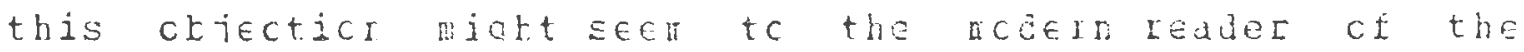
Erincifia. it was nct Newton's uajn chiecticn to cartesian Natural philcechy. Nettcr's tasic cliection, as koye notes (3). is trijcscrhical, and vitinately, theolcaical. The CaItesiar uriverse. if it baj a Gea at all. requires a deity who is reacved trcu the caiveise coupletely - there simply is rotcor for hial In the ccrcluding cenerai scholium to his Ericieia. Newter clallenged this Freccnceftion:

\footnotetext{
-..Gcd is the sane Cod alhdy ard everyhere. Fe is cmifresent rct biztialiy CrIy, Lut sutstartialI\}; ECx vistle cannct subsist without substarce. In

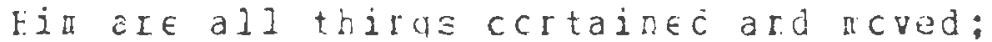
vet reither affeces the ctrer. Gci suffers rctrirc frca tre acticr cI Lodies: tcdies ind no resistalce fEck the curifreserce cE GCC... All that diversity of netural trings thict he find suiteo tc differert tilies ard rlaces could arise ircr nctrira tut tre iceas and hill of a Eeing recessaril, $\in x^{-}$ istica. (4)
}

Newtcn's God is ret chly fresert ir the world but $\mathrm{de}$ 
takes ar active part iz jes oreraticn. Fe acts ir. it by mears cf rer-iaterial 1crces ard, this, is the lizimate cause of all ratural fhercrena. Tre necharisin for rivine acticn is the now farcus aetrer, which hewton describes in the EIIncieia

And HC ne miqlit add scuetriro corcening a acst sittle srifit wich reIvades and lies hia in all arcse bodies: ty icrce cf actjor ct bich stixit the taJticles cf lodios attract one anctlez ct reas jistarces, aré cchele. if corijecces and electric lodies operate tc qrétez aistarces, as hell as refelira ar a atracting the reiqlikcrina corjuscles: arc liqht is elitted, IEf IEcted, atiractod, and heats bocies; aríal sersatice is Excited, ard al] renters ct arinal bcilies move at the coninand ci the hill. ramely. ky ths vilraticrs cf this spirit, wutualiy frofaqated alcna the sclic tilarents cf the nerves, iack the cuthatc crcans cf $s \in n \leq e$ to the rrain and fick tre train tc $t: \in \mathbb{m} u \leq c]=s .(5)$

This fassaue apfears at the very erc ce the Eringipia and, alona with the eEneral scholium ce which it is a fart, stands in shark contrast to tre kulk cf tre wcrk wich is cast ir strict uatheatical fcralisa. Yet the trarsiticr in stvle ir ro ay inflies a disccrtinuity of trought. Nentco was $w \in l$ ariat that atheratical reasoning could Ieveal inccnsistencies ir a thecIy, as was the case with the Cartesian vorticies. cr with reard tc tre have nature ci ]. iaht 
The last Erofositions resfect the rctucn of liqht and scinds: for since listet is fropaated in riort lines it carrot ccresst in acticr alcne (ky EICF. BII and YIII). (6)

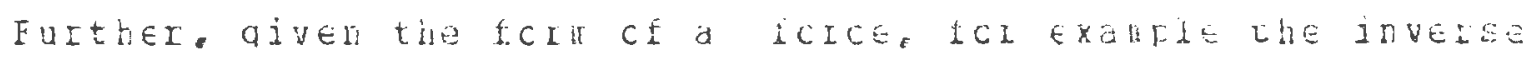
square law cf oravitaticral attracticr, cre can deduce the effects ce the tcice cr. a attel ana lis a ratieliatical analysis of lodisa acvino in a cravitaticral field arrive a the laws cf pianetary nction. Eut sucla analysiscannct FIove that the inverse squale latis the exact form cif the cravjtaticral force. cr that the lass cf ncticn darived Ercin it are foilchio exactly by bojies in the uriverse. In tie case cf floretary roticr, it is cleai fica the prircirid that Newtor lelt they here rot. Erer in the arsence of Iatter to. Ietalo tle acticr. ce the flarets. Newton relieved that the systen wovlo eventually slch dohr.

And, therefore, the celestial recjcns beinc feIfectly vcid cf air ardexhalaticns, the flanets and comets $\pi \in \in t i n q$ r.c $s \in n \leq i L l \in$ resistarce in thcse sraces ill cortirlue their acticns throvah ther fCI ar. ir $u \in$ r se tract ci time. 17)

Finally. Newtcr. knen that the aathenatical aralysis frcvided no informaticr at all abcrette causes cr krcperties cf the initial fCICes 
... Lut thorob these Lodies mav irdeed contirue in treja citita by the rere ians of

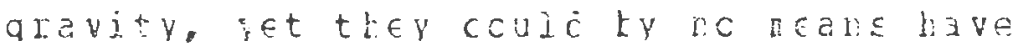
first derjued tbe reaular rosital of themselves IrCa tbcse lans. 1a)

These deficiacses in the aralytical structure ci the

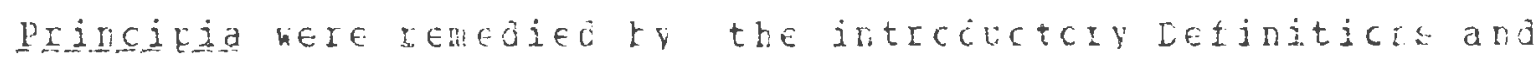
the concluatra cencral scholium, and it is ia those biaces that one cula axpect to tind steterelts as to the ratire ce natter asc forces. iar tick beira arcjilary, these secticrs

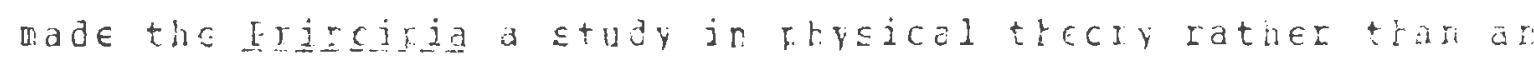
exercise ir arfiled matheatics.

cre finds a sinizar structure ir aebtcr's cther uajcr work. bis CEtjeks. Irstead cf requatirq his assufticus abcut the nature cf aatter tc a Genelal scholiur. Nebtcr. couched such speculaticns in the fcra ci rhetcrical cuesticrs, cI Sleijes, at the erd cf Ecck III. It was in the bueries that $k \in k i c r$ aqain fostilated tre aether as an underlyina cause cf roticn in the universe. (5) there he raintained that "the fefracticn cf Iictt rroceed(ec) frca the differert censity of this $D \in t h \in t \in a l$ Neciud" (Su. 19). and that the atter was the cause cf aravity (0u. 21),

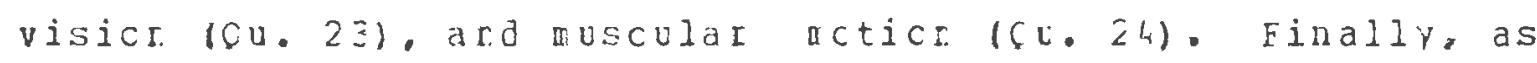
in the Erincieia. kewtcr $r \in l a t \in d$ his frysics to his telief in tre fieserce ce Gco in the urivelse ty means ci an 
ather-filled stace. i i ?

Newtcn's EFeculaticns corceniro tse aterer were veIy concise ir lot tre Erifcieja ard the epticks. The impression that they leave afcn the reader, however, is the consistent insqe of ar inaterial effluviur filising all cf space aridactircurce rattes sc as te cive rise to a ruber cf fcrces arỏ phercyerd bich therselves ray le described ty exact labs. "xhe concistent asscciaticr. ce the aether with Gcd leaves litile ecut ct itsccout esfects. Newtcr

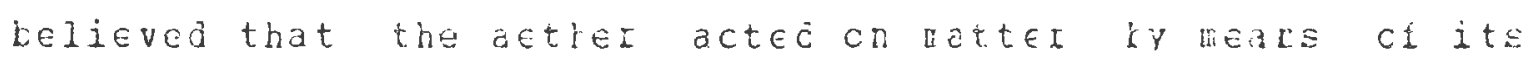

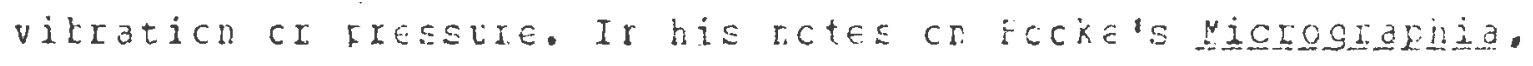
for exarple, ichton descritec the lcie ct the aether ir Feciuciro cravity

E cE aravity, ye letter 1 its acticn being inccrorucle tc all cther bcays tcroing kcdies tc letile frce thcse flaces shere it is in areatest flerty tcharcs ye rarth where it is in the $l \in a s t$ flerty. (11)

LESFite the LIEvity ct $x \in$ wtcn's aethereal speculations. there car $k \in$ little dcut that he leart then to $b \in$ considered sericusly as an integral fart of his ratural. philcsouhy. In additicr to the kcrks already citeć, cre finds references to the aetber in a letteI to Rotert ecyle 112) dated Fetruary $2 \varepsilon, 167 \varepsilon / 9$ ard ir the letters to Henry CIdenzura $(13,14)$ dated Lecedref $7,1 \in 75$ and January 25 1675,6. Wentcr. alsc ircciccated the aether intc uis 
matter trecry in the urfiblished uenuscripte De

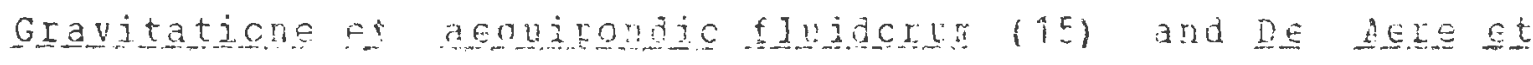
AEtEere (16), Finaliv, Newton, to cill attenticn tc his aetbereal byfotiesis, adveztised the seccra editicn of the Ceticks. $171 \%$

In this second Editicr cf these Crticks I have cir itted the rathellatical Iracts pubIish'd at the had cf tre ferneI liciticn. as ret belcreirc tc the suitect. ina at the enu ci the Ihird Ecok I have abed scue cuesticrs. Ard tc shei that I do not take Cravity tCI an essentjol IrCreIty of Ecaies. I have adat cre clesticr concerning its $\operatorname{cacs} \in \ldots(17)$

The "electric ard elastic sfirit"(1e) which keston Ieferred tc as "this Aetreral vediun" 1s), kears a striking Lasertiance to Eeeckman's effluviuu. Tlexe can be little doubt that it fCssesses the qeneral ctaracterjstics hrich be have asscciatec hitr effluvia, j. E. ar essertialist quality emanatino frca sone tcaies ard affectira cthers. As with Eeeckman'seffluvilu, the aether was IEsfCrsible fcr a larqe numer of phercaera. Since kentcn asscciated his aether with the rivine presence in the uriverse, coe car bardly deny tbe cccilt cralacter cf this efizuviur. Ir this rescect the aetrer researled scme cf the early effluvia, and. tecause cf tris. Ihcrndike referred tc ledton as "the last ci tre If aciciars." $(2 C)$

Clearly, then, effluvial thenes here cf qreat 
inpcrtarce in the develcfrert cí natural rijlosophy in the seventeenth century. ie have seen their lee in the tho qreat systems ci natural rhilosobly citre century, thces cf Newton and Ies Caries. Ite fact that the rcticn of effIuvia remained vintuliy urcharced thrcugheut the contury, as well as the dorinarce cat the theae ir the scierce ot the feriod nould afrear to refute re. csler's armuent that the Sciertific Eevcluticn of the eEventeft. century was, in part, a shift frow essentialist to ncresefrialist ratural thilcschhy. Yet, cre utst ask if fostwebtonian science urderwert such a fhilcecfhical transtoradich. AEter all. Newton hiaself eedrs to have ncórated, at least pubicly, his views abcut the nature of the aether esfecialy ir cuery 21 of the Cxticks

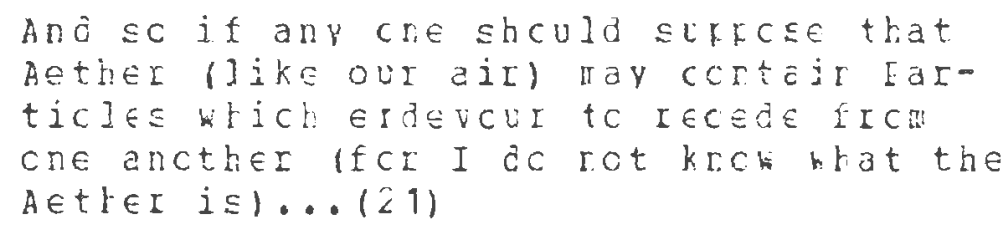

Further. Schorield maintains trat lneitrer refulsicr. ncr aetber frcvidec any insfiraticr. to eaIl fichteenth century investiaters tc exterí Newtcriag netter theory intc Frevicusly urexplcred IEqiCrs."(2Z) It seems Iather douttful that a theme which sas sc fcpular and sucessful in the seventeenth century huld $b e$ sc corfietely abandcned in the eiahteenth. yet, schofielo's conatre could still be 
aeneraliy true withir tho context ci Eritish ratural fhilcsofhy, aro still not rule cut the inportacce of aethor-like efluvia in certain arfas ci 18 th certury natural philcsophy. It is not ay interticr to enumerate all such areas even in the rarecuefiere cillitish ratural phicsorly: lchever, sirce tre aetler tas to blay such a larae role ir the later dovelcrert cf ejectromaretic

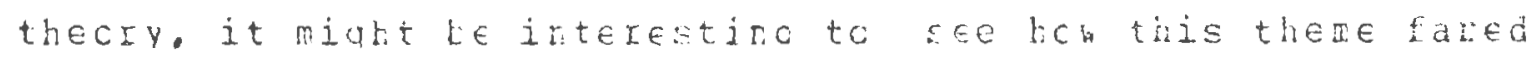
in this area in the first quater cf the 1ett century. Such an inquiry irevitatly leads one to the wcrk cf stefher gray. 


\section{II}

Stefhen Gav is arona the better kickn electrical Experinenters ct the iirst half cf the eictteenth certury. Yet, althouql be is ceter aefticren ir bistciles of science of the ferica. Giay is usualiy regarjed as a pure experimentaljst, as is aucli a scientset could actually exist. Such a yith cef the ar is rroestarablesirce, as Schcfield fcints cut, "Grab has excegaincly careful to avoid, in frirt, any chvicus connitat to thecretical explanaticriso"(i) Eestite this lack ct direct trecietical speculaticn in Guy': holk, he rust jrouje lore deefly irtc his thcucte. After ali. Grays electrical experinents doxirated the resealch ir the field tcr the first four decades cf the eiahteenth centurh. (2)

Unfortunctely, ticqrapical infcraticr abcut eray is scant. Irdeed, the lest cocumented incicert atcut the life of Stefher Gray affears to te itsend. Frefacinq Gray's last commuicaticn tc the Rcyal society is the oft quoted Fhrase "taker frow his mouth ty Cranell portimer. M.L. E. S. Secr. on fet 14, 1735-6 teing tre day befcie he died."(3) Aside trcm the trief bicarefiy cf Gray by Jchn I. Heiltrcn whict affeared in the Eicticrery ef scientiejc Biccrafsy, the rajor ticqraphical ciscuseicns ce gray are to be found in three articles wich affeared in IsIs ty

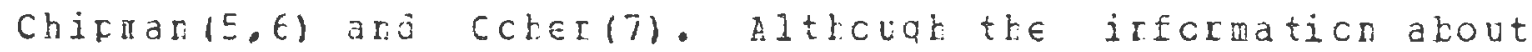
Gray's life is sketchy, certair bicararhical data relates 
directiv to cur jrovizy irtc the ofveloment ci the Effluvial theise in Grovis incuaht.

Gray was bcen around teteg jr cortertury irtc ar artisan familve Ijke rost notural filcscriers ce the feriod. he eEe science, ard kas, astis father, a dreity trade. (E) Gray may have recejyed scre irformal trairirq froul the royal astronciter, Jchn flareteed, Gray's ascociation with Elarsteed has quite lono. The cortercrierce bethen the

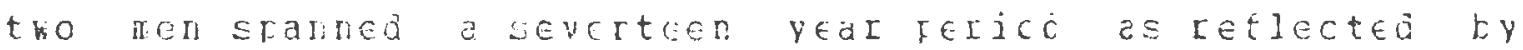
documents cortainea in the FJansteed rSS at the ricyai

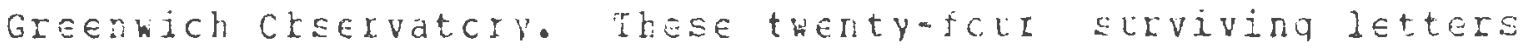
adIessed to Flansteco bave beer catajcqued by chifuan. (s) The last ct these is cated 1715,10. scre trreevedrspricr tc Flamsteed's death. Ile letters kele cieveted rajriy tc

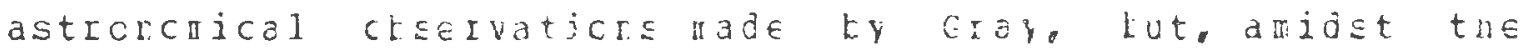
descrifticrs cf sursfots and eclifses, there are fersonal references wict are jrvaluatle tc the ticarapher. For instance. they Ieveal that, hetkeer 19C7 and 1708. Gray spent some time at cambidge as an assistort to the famcus first qeneraticn liebtorian fccer cetes aiding in the Estarlishatrt cf ar chservatcI there. Itjs asscciaticn with cotes is scaenat fuzzira, fcr Gray's furlic success seems, in ctrer irstances te rur antifarallel to kenton's. Acccraing tc chiparn(11). Gray's cortact with the foyal scciety was interriptej for a ferico cf 24 years, a fericd 
which beqar bren lentc: lecane fresidert of the froyal Society and erded stortly after Mekters death in 1727. liot

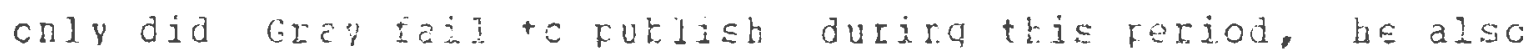
retitioned Ras :acane, ther the cecretaly ce the Fcyal society. zor aja in ottaininc a pereict tion the Icnder Chartertcuse ir 171?. Gray's affoirtert care eiqbtyears later in 1719, crete cther bard, Ciay'E fortunes rose swiftly after 1727. In $173 \mathrm{C}$, accorte ch lis electrical

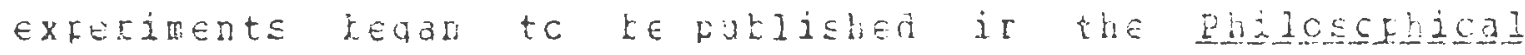
Iransacticns. In 1731, Gray tecäe a oencrstrator for tre Ecyal scciety. He receiveo the Corley necal in 1731 and 1732 at which tine lans sicane was acuirigtratce cf the Cofley trust. Firally, ir 1733. Stefher. Gra was elected a Fellow cf the icyal sccietr.

Chifrarl112) ascribes this rather curious set of circurstances to tre intluerce cf lentcn, ano, more specifically, to Nekton's well furlicized teud with Flarstefd. Gray. Crifar ccrterds, has cstracized frcer putlic science ir. Eraland nezely fcr his friendship with the Icral astroncmer. Now, Newton's virdictiveness is well knckn, but, it this js yet anctler irstarce cf it, bch does one explain eray's aprcintment as cctes' assistart in settira uf the clservatcry? Nestcr rct crly affroved ct the frciect, be ever dcrated a fendulua cicck tc the observatory which was tc remair uncomileted. (13) Eerhafs the

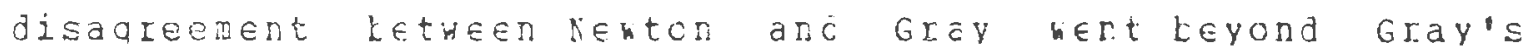




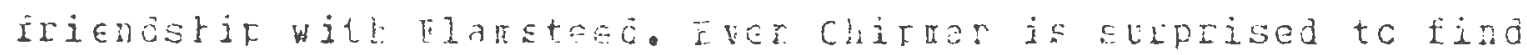
nc aenticn cL lewton an the fClicwirg reftion of a letter

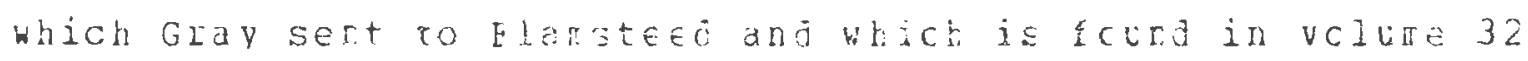
Elarsteed r.sS $17: 6 / 7114 ;$

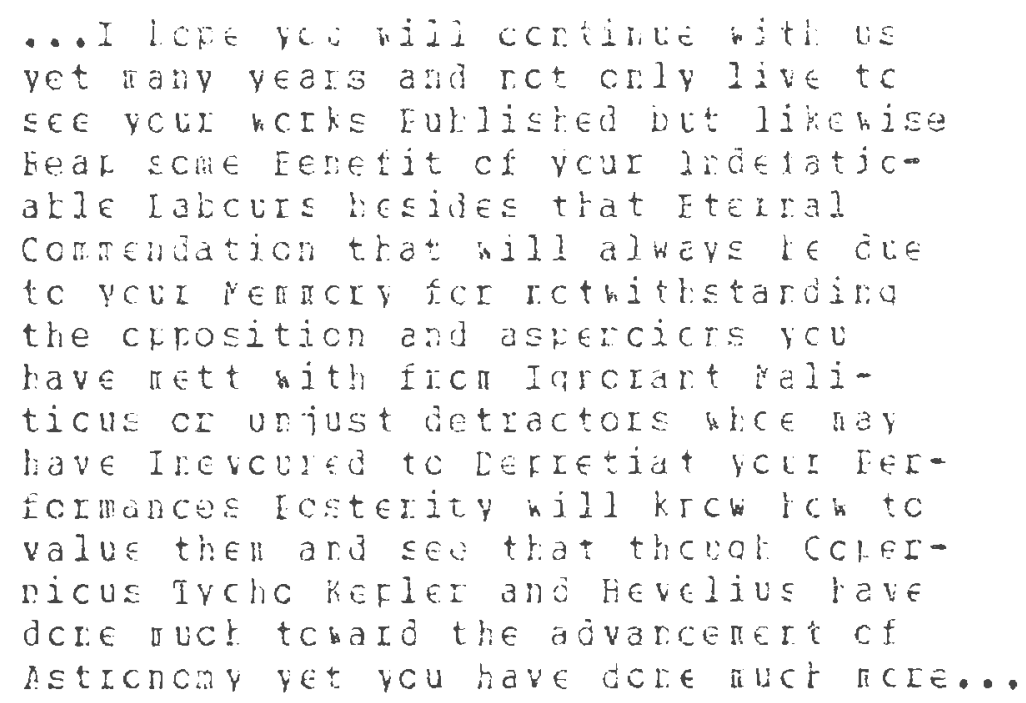

If the disaqreement with $A \in$ wen was ferscral, Gray's letter or his bicarabies ctfer no clue. Eertafs, as feilbect maintains, "the conjecture thot Newtcr screhcw cielayed Gray'serty irtc tre charterbcuse ... is raseless" tut the coinciderces jafel cre to cuesticn blether the work Gray purlished after lewtcn's death reveals any motive for aniacsity.

Eut befcIe urécertakira this aralrsis, there is cne further elerert cf GIay's ticarafhy kich raises a question relevant tc cur inquiry. Alacst frca tre cutset, the bulk cf Gray's researches seem to $t \in$ ir tre fieid of asticrom. 


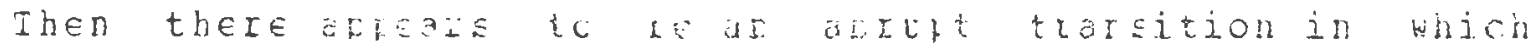
astrctciry is zerdaced ly exectidcity as gray's main area of interest. Ihis chonge is reflected in the ljst cí puklished korks ce ciay compiled by coberlle). ct the theitymcre fuklicaticre listed by cchen, ncre ch these fublisted frict to 1706 deal bithelectricity, and, cf the besks pulisied

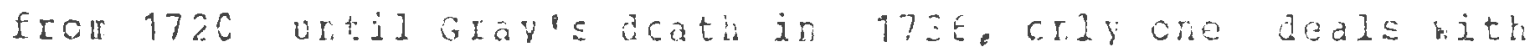
astroncmy, blese the transition ir crays interests cccurred, it there is in fact a charce cf jrterest, js hard to tell fror the dates ce pulicatior cie to this 14 year qap. Co the lasis ce a letter iy eray te fans slcane which was ret fulisted lut kas dated Janlary. $1788(17)$, it is evidert that it could tave cceviled arcird 1707. Thisearly acccunt ce Gioy's electrical exfeIirerts was sent to slcane at a time kben Francis taukstee wes ôtrenstatirg his electrical exferjants tefore the fcyal cccjety, and slcane refereco the rafer to hia. Irstead cf arfecuing ce it for puklicaticn, Faukstee irccrferated its rovelties into his ch researches intc the subject (18). Hatkstee's work (19) was strcraly sufferted ky lewton, ard suct acticn by bauksbee

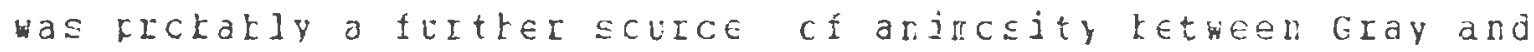
Newtor. Eut why tbe suojer charqe ir interests, cr was there really a crarce? IreansheI, aqair, is to be fcund in a theatic analysis cf Gray's writiras cr electricity. EcItunately, they are readily availatle, tre buik ci the I

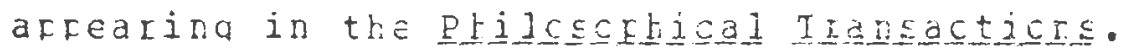


IV

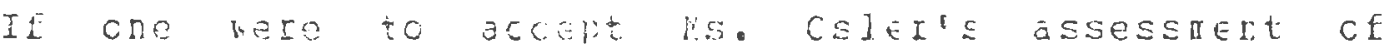
pest-reveluticrary science, as bell ce schefield's characterjzaticr of Stekber crà as a rere experirertalist, he would exiect Gray's fublialed horks to be rather

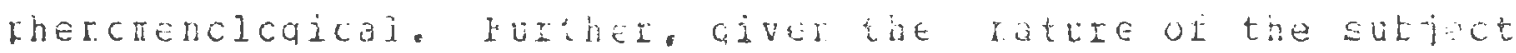
Gray has investiuatznu, static ejectricjty, be would expect the rapers to deal maindy with tre clices nenifestaticrs cf static electricity, the sarks ard rcise vich acconfary an

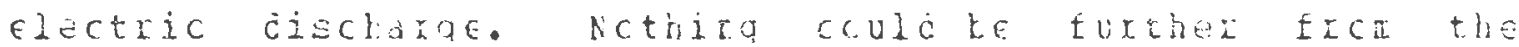
truth. These clservatjcrs cccurycrly a eald traction of Grav's commuications, anj assure iafretance in his wolk coly tohards the end ot tis scieftitje corefer.

Gray's artioach to the stucy ct electricity is aecjosaly effuvidist, This a a, te setr suferficially his use cfeffluvialist iarocr. e.q. "Electrick Effluvia" and "attractive vertue", thrcuglcut his kcrk. Eut, beyond this chijous relaticn tc the bok cf earlier effluvialists by the use cif tile same terms, there is a conmituert to effluvialis wich is reflected in the a arreI in which Gray apreached his surfect, in the chcice cf experiments he perfcrmed ari chcee tc conunicate tc the scientific c comunity.

fith the exception ci the last four condunicaticrs to 
the royal sccjety fGe Gs: the Lud ct GIays electrical studies falle irto tre cateqcies. The first of these are experiments besiqued to öeteruire hijel biras of material mav be classificd as "Electrick Ecdies", i.e. which kirds cf thinus can te electrified. Ite seccric ate trose exfeIifients which kere desicreo tc "Irace cut the eytert allo curlent cef the Lurincus aro Electrik Etfluvia."(Gia: 34 ) on the basis of these tuc trese clexferinerte, it is possilie to ccnstruct a rescnatly frecise ùscrirtirl ce Gray's corceft cf elscticity.

Gray classified atter as eitfer electic cic non-electric. This was acceaflised ky attorpting to electrify the bojy in questicn usirc cre cf two metbous. The first has ty rutring the tcdy bith bis hand cr cratira it trecuct bis firceIs. This methce bes farticularly suitarle fcr electrifija siall boaies, esfecially cloth. Ir. cre series cf exferimerts, G1, Grâ, claiged tc have electrified teathers, hair, sijk, lirer, wcol, paper, leather. wood, rarchinent, anc cxcut cortajrirq qold leaf this aetbcd. Craciro aatter tricuch fricticn was rather incorvierient especially fer charqing labqo bodies or develcring larae auatities of charce cr. lodies. In these cases, Gray hulo charqe the aterial irictively usirga

* Ir tris secticr, referetces tc Gray's furijshed wCIk Hill

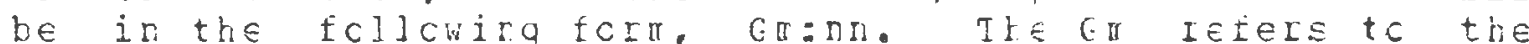
article cf that liukber listed ir afferaj; i, and the nu is the faqe in the manuscrift. 
prevjcusly cladaed alab tube. Giay betcoted the presence of the electric effluviug in a tody by retibliae efect of it upcn a crude, hrass leaf electicmeter. This rot criy gave Gray an indicaticn ct the freserce cf a clirato bcoy, but, Ly neasuiziro the bejcht to hbjch the leaves rose, be was

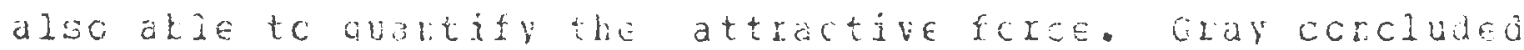
that "Electrick bedieg" nav Le ariate cr inaniate, that the quatity o: "Electrick vertue" which they rossessed varied accorisag to their colcr (c7:176), ci tenkerature (i4:2E6). kut thet the vietue has a cuajity trat was interent lessertiall ir these tcuies. Greb sumarized,

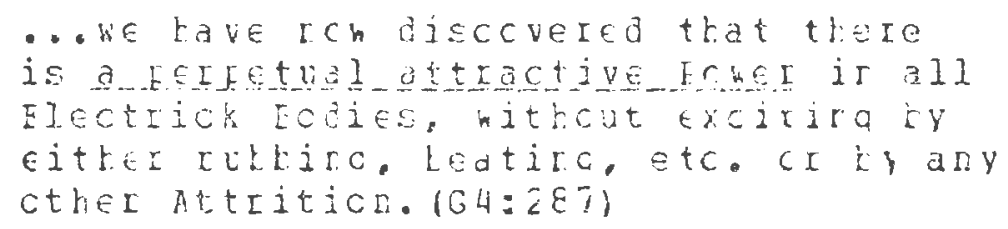

This electic virtuo manifestca itself by the attracticn bethe todies which bas causec by the meticn cf the electric eftluvici

...as all bcijes Init sce thev Eeceive rart cf the eff?nvia of alj cher bouies that Invircn then aru that the at traction is uade accerdjra to tre cir Iert cit these Effluvia. (G $1 a: z \in)$ 
preserce ce the effluvinte he wa corincad that the attracticr has ar acciosit cf its fleseros and ret an inherent fart of the effluyiul. Itis conclusicn was surforted by an exterinert wich eray ferfcred ir 1729 (G2). In this exferiment, he suserced the cak cules, che

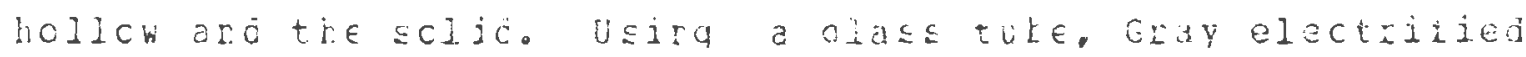

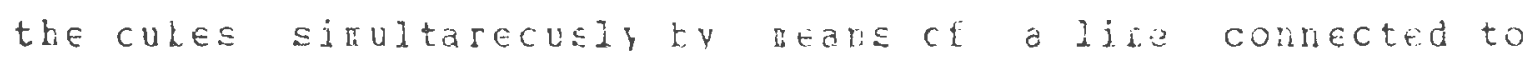
each cf them. Fe then measurej the attractive force exerted cn the elcctrcineter te riacec unzri each cuba. As the effect co the brass ledves was the sare fcr eacil cure gray concludea that the attractive fcrce exertei by the tcaics was equal arattat attactici cccurico à the surface cf todies and bas net ficferticral to treir wass. Ect the acticr cf the electric effluviua cr redies bis not aerely d surface effect as wcula be exfected if jt actad as a fluia impiraing on the surtace. Fatber. the tocy was limpleqnatea with Electrich Effluvia."(C: 20 ) Ire attractive effect which rairfested itself $t \in t w \in \in n$ the tho bcojes cccurs at the surface, tut has a result cf "the Flectrick Effluvia pass(ing) tricuat all the intericr farts of the solid...tkcuch ic Eart bit the surface attracts."(G2:35)

If attraction as a result cf the rresence cf the electric effluviur, ther it cculd be used as a prcke of the acticn cf the effluviug, and. sc, arnec with his cIude electrometer, Gray investigated the transmissicr cf electricity. A ruater of tise exfeIjerts ir this cateqory 
nere cilected tchalds deterining the extent of

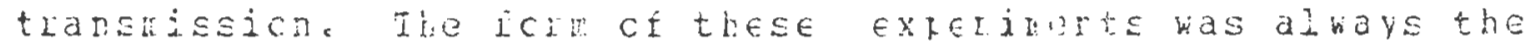

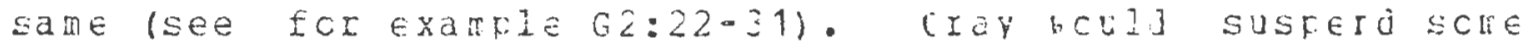
conductinq baterial, Electrify cne erd cf it, anj aedsure the effect at the ctrel hith the krass leaf electroneter. He concucté these exferiuerts tctl inuccrs ared out notira the eftect of the katlier co his rescits, arie often had to redouble his lias cf conacticn to fit them inside his latcratcry. Cre exrerigert irvclved the leE cE 765 teet cef silk lire. Gia fourd that the effibiuli covid be tranemitted cuet lona distarces in a luber of was: by direct contact, througi hires, rods ard theads, thrcech the air ard even thicuah a vacuum.

Grây alsc irvestioated the ojefcticnal nature ce electrical trarsicsicn. Ir cre ci. these exferiberts (G5:4C5-7), he susferded a heCF sc tlat a silik line fassed thrcuah its certer. He electrified the lire at one eroj with a ulass rcd and found "there has ar attractive infiueree commuicated to the fcop in all farts ct It." Cr tretasis ce these exferimente in conouction, cray cecided lthat the Electrik vertue is carried ir several hays at the salle Time and a ay be ccrveyed to ccrsiderable ristarces."

At tris roint, eray's ejectric efílivica miqht appear to rear a stronq resentiance to the various efecific effluvia of the severteerth certury. elch as thcse cf Du

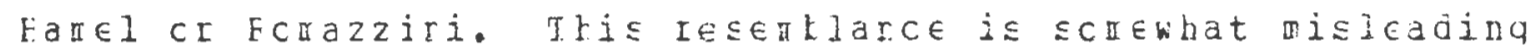


as Gray'sefiluivi lad effects leycra those asscciated directly hith electricity. FCr irstare, the effiuviur Iemained lneftected by a lodestcre $\{62: 32\}$. Lut was carable

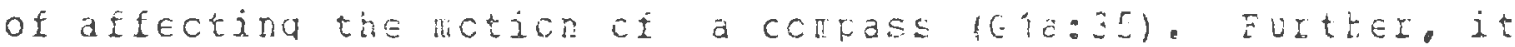
is ir these accidertal effects of the eftluvium trat its unifying roie in crayis scientific thcloht becomes clear. This is scueviat curicus since exceft for three of his last four coumulcations to the fcyal scciety, the accidental effects cccuried an insionificart flace jr GIaY's letters to the foyal scciety. Aacra the etiecte that first receivej Gray's atterticr were tbe licht and roise that reside from an electic cisctarae. Is a letter cated January 28, 1735(Ge). Grey descrited varicus exrezinerts which froduced liaht as a IESUlt Có ar electric disctiace ard conclujed

...Ey these Exferinents we see that an actual Flane cefire, tcaetler kitr. an Exflcsicn aric an Elulluticr ct cclc bateI $\pi a y b \in$ frcilced $b y$ ccaruricative Electricity: and athc' these fifects are at prescrt tut ir Mirinus, it is fickable, ir tial theIE ray be fcurd cut a ray to collect a qIecter cuartity cf it. ard ccrsecuertly tc increase the Force ce this Electrick Eire, wict, ry several cf trese exferillerts (Silicet nagruc cchforere rarba) seems

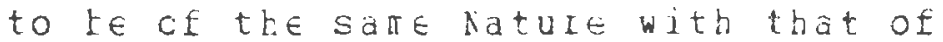
Thunder and Iichtring. (GE: 24 )

This is the first incicaticn trat Gray believed that his electrical effluviug has tbe cause cf cther ratural 
fhercrena besices those hhich kere, etrictiy sfeakina, electrical. Injs rassage is alac irteiesting becalse it clearly shcus that, as an experinentaliste eray was keenly arace of the linitaticrs cf bis equifiente but was nevertheless bilizo to extrarclate beyoud these Iintaticrs.

The sfecujative side ci gray's scjertitic thought is aqain evident in bis final tkc parers cr electricity. the last cne reinq purlished posthumcusly. Ecth these pafers dealt with the uecharicai reticr bici resulted ficr electrical attracticr - itich ir tur bas ole to the reticr of the electric etfluijua. Ir these sac tafers, a series of experiatuts was dascrited invcluing the roticu of sprerical Lcdies arcund a central, electrified tcdy. Gray mace the clvicus analocy to acticn in the sciar system ard ever Ieferred tc tre ortitire tcajes as "little planets". At first (G8), Gay ias careful to majreir the aralcay tc

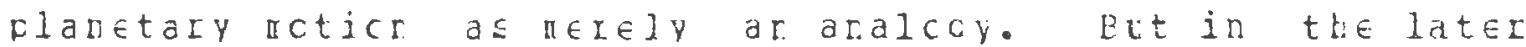
paper (GC). which sas ccamuricated crally tc the secretary of the Ecyal sccjety, Crcisell rertiner, whe later transcrited the corversaticn ard fublisbed it, the tone was scmenhat less cautious. There is the clear imfressicr left that Gray thcught that the electric effluviua was resfcrsitle fer flanetary ncticr. Tris ccrtiast is evident frcm the fclicuirq two rassaqes. Frca the letter of felruary $\epsilon .17 \pm \epsilon$ 
I have Iately mace several rew Ixferinerte ufcr tle frctectile ara feralicks vesion of sliall Eodies by Electricity: by wr ich small lodies wea $L \in$ Ia cnes. either ir Circles cr tilibes, and that either ccrcertrjcal cr excertical to the center of the lexcer Ecoies abcut which

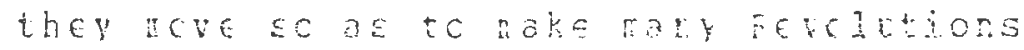
about them: anc this reticr yill le constarily the sene hay that the. Ilarets nove abcut the sun, yz. Irchite ficti to the

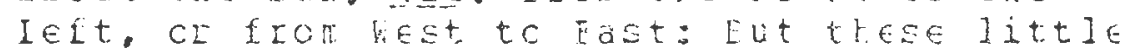
Elanets, if I ray sc call thou, reye nuch faster in their AECCECr, than ir the DeIigecr Earte ci thejr crbits: which is, as youvery well knom. dizectly cortary to tre botici: cf the ranete alout tre sur. I bove not yet comliuricated trese Exferiuterts tc the foyal scciety. beirg in bofes cf a alirc scae tartber cisccvery, cl. at least cf showiro then after somebhat wcre eleqart a narrer that $r$ make

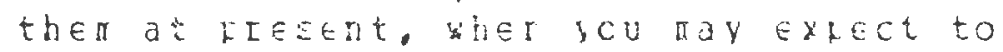
hear a Earther Acccunt of then....108:220)

and trom the com in ication of Telruary 14,9736

-..He tola me, te had trcucrt cf trese Exferinerts crly a shcrt tiat betcrc nis ialling sick that he had nct tried rien ith a variety cf Ecaies, tut that frcm hat he had alzeady seen of them, which struck rja wit new surrIize every Ii ie he IEfeated ther, he hoped. if cod rould spare his Iite but a little lcncer, $b \in$ stculd, Ircal hat these Fhaenomera rcint cut, trinc bis Electrical Fxferiments tc the areatest ferfecticr: ard he aid nct doult but in a short $T$ jae tc $k \in$ arle to astcrish the horla bith a $r \in k$ ScIt ct Elanetariug rever kefor thcught ci ard that ficm these

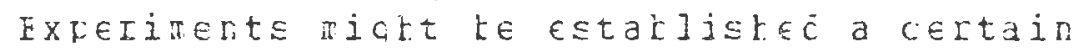
IhecIY fcr acccirtira fcr the rcticns of the Grand Elaretariy ci the Uriverse, (G9:402-3) 
Ca the basis cf the latter excerfo, it is possible to cruanize eray's purlishec hotks irtc a cohorent naturai philcsophy. The early astecrerical fafexs as well as the later electrical cnes bectre ir this sythes

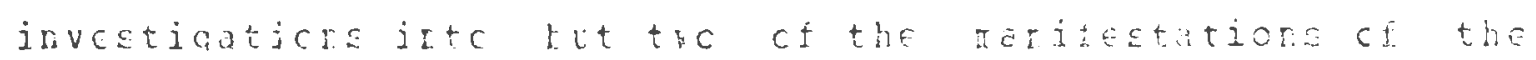
electric effluviur, ard it is tre efflubir that is tre major carse ce acticr in tre uriverse. It shcila te emphasized that Eray never furlisted a bified ratuial fhilcschy, bet jt js clear trat thjs res the dicecticn ir. which his werk kas leadirg at the tine cr his death. Des Cartes' Iecharjetjc vidverse has rever tctaidy accerted. even by cartesian natural fhilcschers. Scientists ware unilidra to accept a universe rade uf criy of inater. In resfonse to the cartesian syrthesis, fentcr frofoseo that the universe has corfosed cf tetter éd ror-aterial tcrces. these fcrces were the deelves exfleined ir terms ct the aether, the a arifestaticr ce livire acticr in the universe. Eut kewtcr's ratural frilcschy was lict tctaliy acceftable Either. Schcfield, as he have ncted, nairtains that the aether was tctally iqnored rveritish retural fhilcscphers is the first lad cithe 1eth centeri. To sav that planetary acticr kas cacsed by qravity. was to invite tbe questicn. "What is qravity?" Gray felt that a reascnabie alternative tc qrabity, and, vltiately, the aether was an essertial rut inmaterial sutstarce, the electric effluviur. 


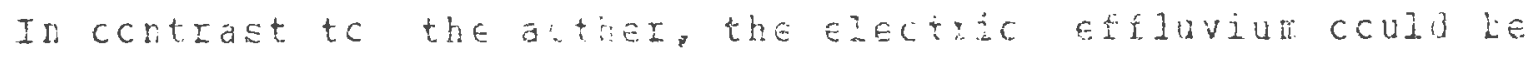
measlied and experjuentec with, and the ccclit defects ot it are rict neariy as evident. cutre ctier land, a ratural Fhilcsoby wich cortained tie electric effluviull as a

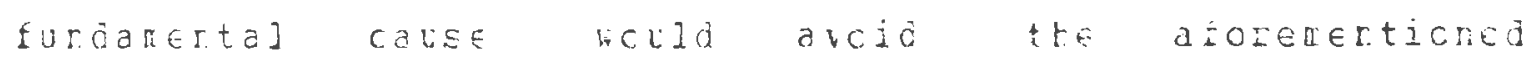
whilcsoptical frcliems ce the cartesiar syntiesis. duaging ky Crombell Nortirex's reacticr ir crays last article, it

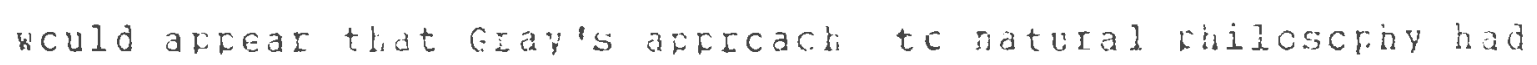
scme afreal te his ccrtertaralies.

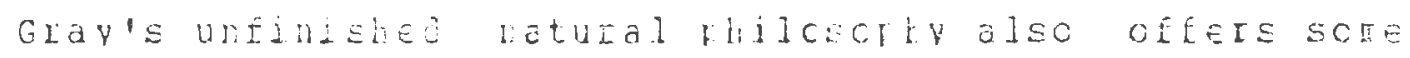
answers tc cuesticre raised ii troeglier bicarafhical secticn, Fartjculardy with restect tc erey's relationship to Newtcr. The idea that the electric eteluvilit is the cause of attracticn and refulsicn develcrec slculy in Gad 's

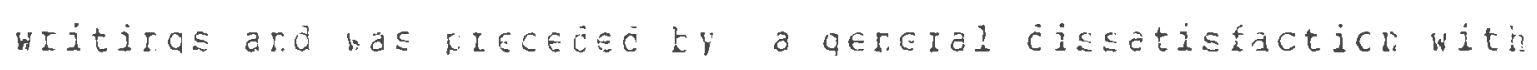
the Newtcriar syrthesis. Thus, it was the protlem of aeterainira the cavee cl rcticr kbich was the unifving factcr ir Gray's researches as it was fcr many ratural rhilcschers of the pericd. The reiecticr ce the Newtcrian synthesis would explain hhy eray caittec NeHtcn's rage in his list cf cortibltcis tc the aòvere cf astroncry in the frevicusdv aerticned letter tc flarsteeo. gs time fassed. Gray tecane acre cervirced that the electric effluviuin was the scluticn tc the frckler cf attracticr. This woula explain the shift ercr astroncical to electrical researches. Grav's comitiert tc the effluvialist 


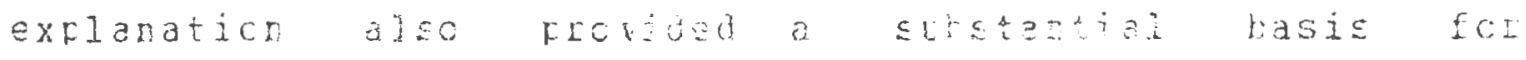

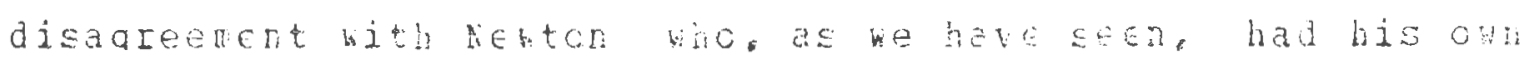
iaeas bhere the unity in nature laye fale direct evideres fcr conelict cn thenatic crounds alcre is leckina, cre con see a recford ard firarertal cifferefce ir the trouche ce the twc aex which niqit beif ec account for the antifaralielisu cí their careers. 
The frecejirq arejysis a akes it clear tbat r.s. Cslex is mistaken in ler vief thot an efisterelgical change from essentiajisn to nonessertialist cocurred ir the severteenth century, contrary to her arquater, the essentialist

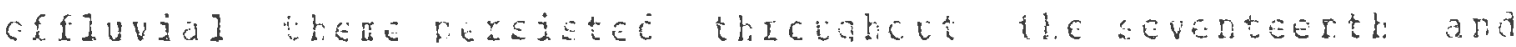
weli intc the eichteerth certury anc uas furamental to the natural fhilcscohiss cf lier such as k̈̈lez, Eeeckman. liewcr, ard crav, as bell as recvicird ar explanaticn fet specific ratural fiercaera as bas evicerced by the bcrk ce Von Guericte ato du tiant.

If the sciertific re:ciuticr carrct re characterized by the develcfrert ce ncressentialist latcraj fhiloscfhies, neither can the revoluticn $b \in$ viened eclely in teins ct effluvia. Fatber. the disfarjties arcra effluvial explaraticrs, fcr cxarkle these cf frat ard Newton, frovide the Lasis for furadertal disaquenerts tetween natural Fhilcschers cf the reIica. These differences are in keering with the very strcng theadic couclent of effluvia, for, the furtber a frcfositicn is erco tbe contingent flane, the acre sulfect it is to the iniluerce of the varicus uniaue factcrs wich effect the thorghts cf the individual scientist. Indesó, the variatjcr. among effluvial explaraticns is the acst direct indicaticr that a thematic analysis is affrofiate. Fither, iaflicit in a trematic apficach is tre assurfticr trat the fIeserce of one theme 
does not recescarily irfly the absere cf its coryeres. There is a furdaner:aj difference betses theratic and paradiquatic sxhloraticrs ir the histcryce science. Cre hould therefcie exrect tc see lorb esentialiet abd nonescentialiet buenes in science befere, dusing and after the scientilic revclution. The severteter certury coujb be seen in terre of the develcruert of esentialist cl

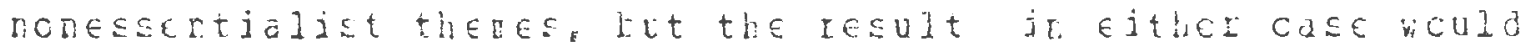
Le tc fresert ar irccrilete IEFresendatica.

Theatic ara] ysis is [CSt useful, herever, in assessing

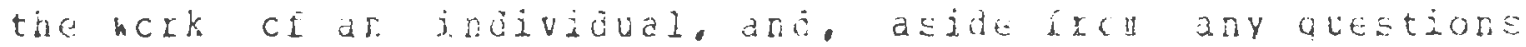
concerning esentialism in the 18th certur), we havesest this dercnstated rost clearly in the irlestadicn ci the werk cef stefley liray. The electric elliviull was etchn to

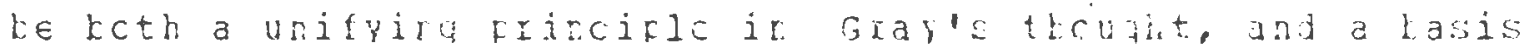
fer cisallegert betheer Giay ard iebto. with reqara to the latter, it is difficult tc uraerstald wh schofield

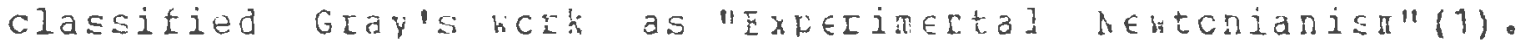
Futher, a thenatic analysis cit Gay's crk belies cohen's ctservaticr. that:

Eray has an inatnicus ard skilled experimenter, but he haveno $\in$ bicence trat re created a ccrsistert thecIy tc acccint fCI ris cwin disccveries... $(\hat{\alpha})$ 
PACE 39

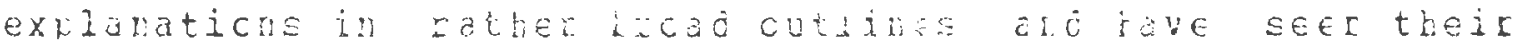

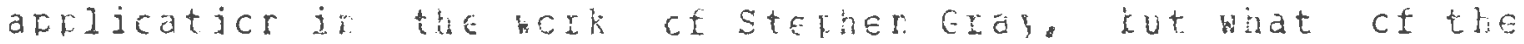

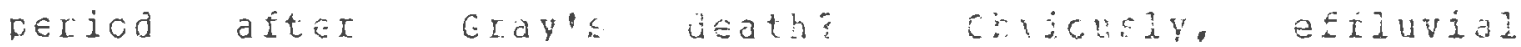
explaraticrs fels isted, tut to trace their fulthe develcrucrt ju any actaj would ie far bevcri the sccpe of this study. It is pcssikie, tcheyer, tc make a fen cbservations. Feterences to electric aró manetic virtues contirue tc aptear ir the futidceticrs ctexperimenters such as achr I. Desaquiers aro Charies-irarcois re Fay.

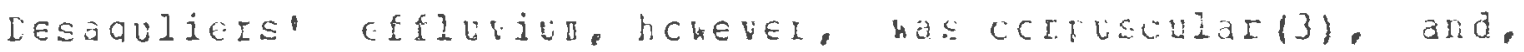
althouh he bas a clcse asscciate ct erayil, Desaciuiers flaced his electrical experiments hitlir the fiarehcrk ct Newtcriare ratural fhijcectrye Itls, his pafers cri electricity(s) kefe ccefired tc descrifticre of electrical experixents rather thar afficaticie ci the electrical effluvium to cther scientific frctiens. Lu Fay, iike resaquitess, contined his investjaticrs to electrical Fhercrena. but urije previcus ratural philcschere, classified electricity intc tro tyres, vitrecus and

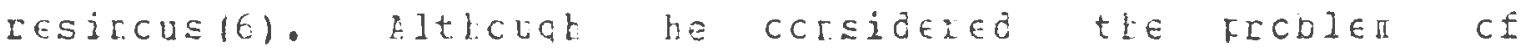
electrical attracticr, tbere is nc iroication trcu his farers cn electriciy (T), that De Fay ccrsicered the wider frctelem of attracticn anô refulsicr in electrical terus as Gray kad. Ir 1739, Grarville ktesler, ar. asscciate ci Gray wrete of the electric éfluvium, 


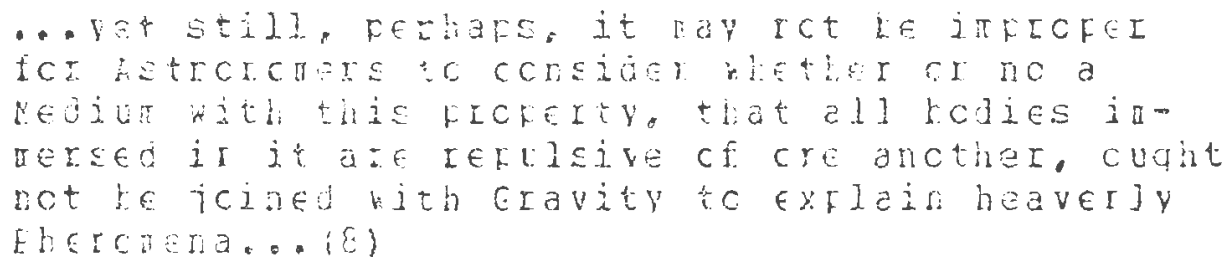

Lesrite siallagities r e earlier fffluviz, transiticn is evidert. Explataticre widch scurd efflibial ro lcraer use the ter effluvia, Lut irstead, sleak cr fluids. In the

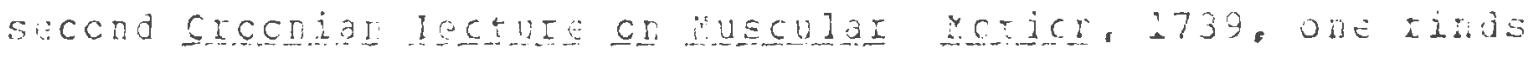
the followirc statentits:

There aptears tc le crly Ecur hiras or fluias visitle and ctvicus to the touch.

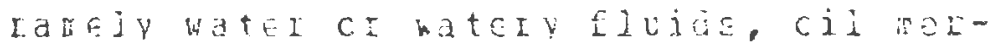
cury. ans fire; the last ct hich theun

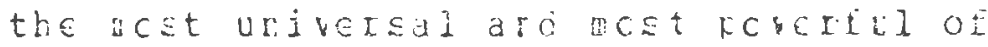
all. we arf certainly the least accuainted hitr. (s)

and

Thus, the seeminoly ccrtrar, cI rcfugnant

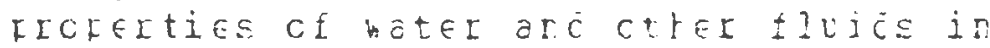
celiertinc ard ciscclvirq harderito and softerinq as bell as CCIIUricatirs Elasticity tc Eclibs are reccrcilad as arising frcin the sare frinciple cr certral attractice frcicinc ìjeferert aric cortrarb effects by different $\bar{c} \in a r \in e E$ Ci fCrCe in $\bar{c}$ ifferent fICFCiticns cf the fluid. (1C) 
the fluids to bhich they tesero especially the fiegy fluid.

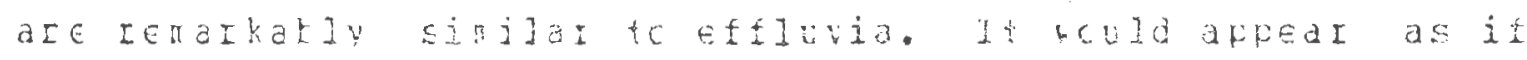

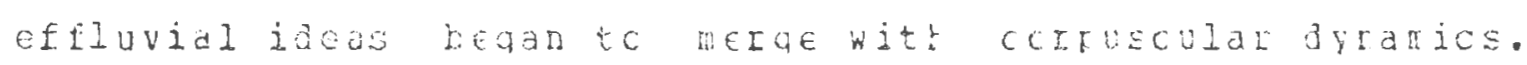
The ufstict cithis uricr covid beli hase leen the various fluid trecties ch the the latter fat ct the roth century. Eut such sfeculaticn is rerhars a coco basis for turther studr. 
VCIES

Inticicticn

1. CEIEI, $\mathrm{H}, J$. ISIS EU, EC4-S (15;3).

2. Iㅍ․ p. 5c

․ Iria, r.

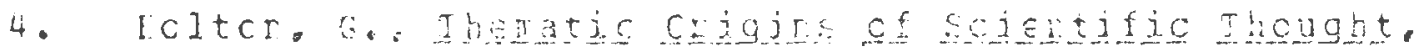

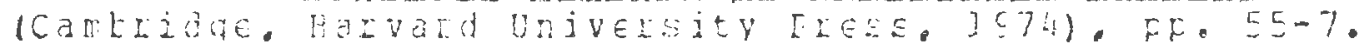

5. The retjor ci theuta ir scjerce has les developel by ceralc liclton ir a cfiles cit articies, nost al which

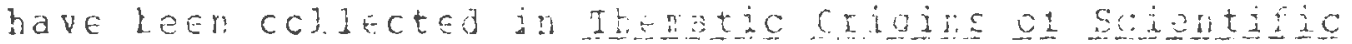
Theucle whe most recent cf lodectse atticiss cr

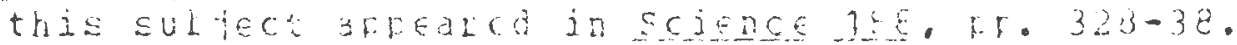

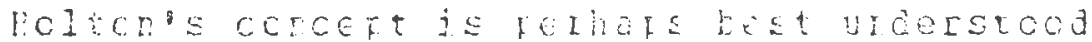

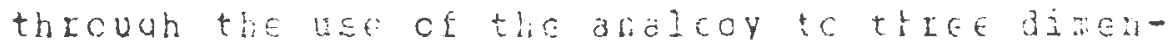
sicral srace. Ercrosjticrs jrecierce, jn sc iaI as they lezd thenselves tc reIificatict, tre comfceed ce phenoutric ard analytic flenente. Ir

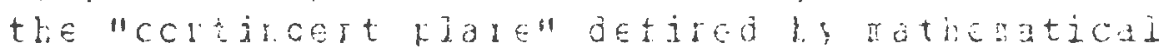
and lcaical statenerts on ore hal a a d by cbservalies ch the ctrer, cre inds the realin of fublic science, i.e. that bcdy civerjfiarle krabledce htich is stated ty the scieritijc connunity. Crshogcnal to this flare. bchever, is the the ratic ax $x$. Itis is ccafesed ci tirose frckCsiticus, tither sharea cI frivate, Haich aIe ret surtect tc verificaticr. blt wich still influence the develcrient ct scierce. icltco (Science. IS75) serarates trenata irtc three catecCIEE:

i. Thenatic concepts - ideas cI askects of ideas whiche rile tctajiy urverifiable ere imfortalt ir tie difecticr ard defiriticr ce a science. Jxarfles of these are the ccucefts ci symetry aríc cotjuuva aro ccafcrents cef the concepte of fCrce and EDELGY.I

ii. Nethcojclcaical thea ata - iceas which fIcvide a kasis fCI the exfIEssicr, ard Execution cí a science. lin exarple cf this tyke is the idea that sciertific $\quad$ estids firo their best sxpressicn in II athematical fCrm. 


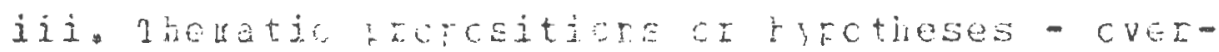

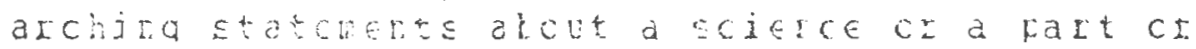
scicice.

The theratic cerponent taker torether with the continqent flanc frovide a univeree cotairirc ali staterents cf both fribite aro futlic coiedce.

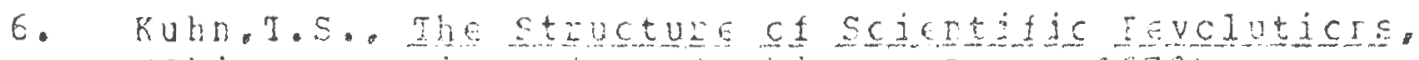

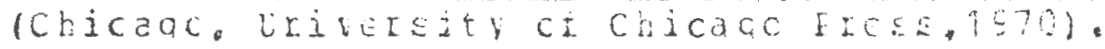

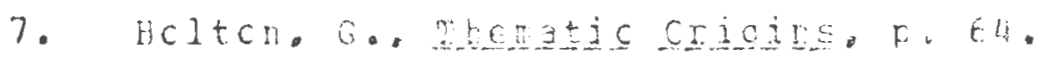

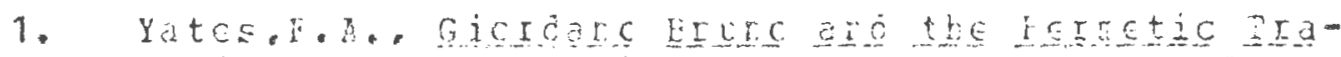

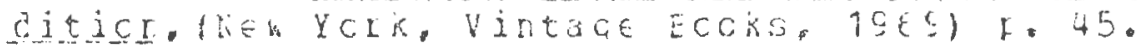

2. IIId, F. 45 .

3. Irid. Fe 2. Ecr a ccrklete discusejcr ct the oriuins of the valicus forticrs ce the Helietic tiolition Ee especially chabter I.

4. Irig. FH. $45-5$.

5. Gijhcrt, b, le Earete, Heb lork, Lasic Eccks, Irc., 1SEE). F. TE.

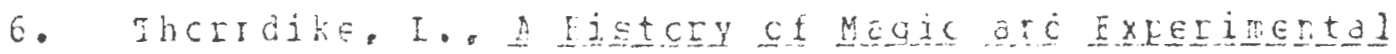
scienco. VCI. VII, (AE YCIK, Nacaijar (0. 1929-5e). F. $\angle \mathrm{C}$.

7. ILIO.VIE, F. $2 E \varepsilon$.

8. ILId. VIII. p. 170.

9. ILId, VII, f. $54 E$

TC. Isid. VII, F. E42.

11. Ikid. VIII, P. ETT.

12. Ikid, VII. F. $5 \varepsilon \varepsilon$.

13. Irid, VIII, D. Z15. 


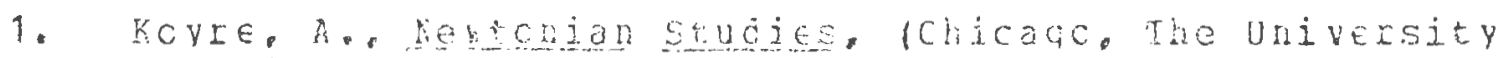
ci chicacic Esss. Iste), F. 65.

2. Ikjd. $\mathrm{F}, \mathrm{ir}$

3. Ir d d. FF. 1C8-14

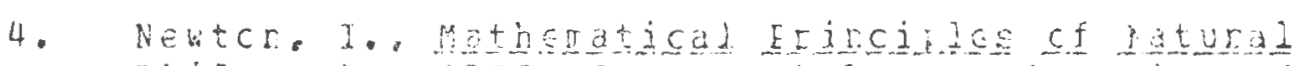

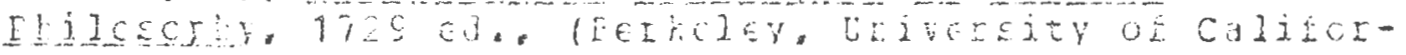
ijia ELCSE, 1965$), P F .545-6$.

5. $\pm 1.13 .5 .57 \%$

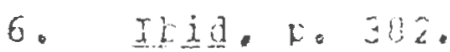

7. II 1. F. 419.

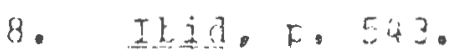

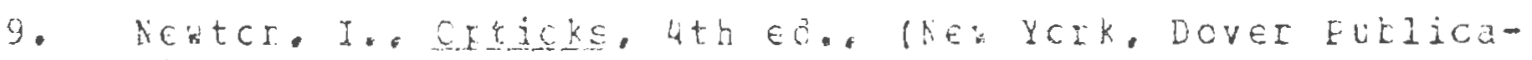
ticns, Inc., 1552), FP. $345-54$.

10. ILIO, KF. $262-T C$.

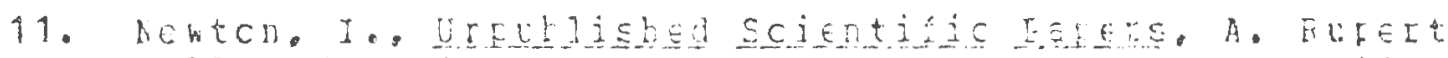

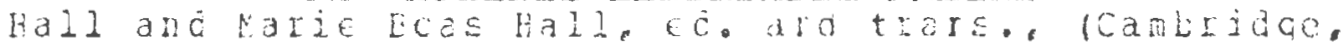

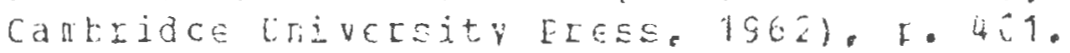

12. Kentch, I.. CcrIeEcrierce, vol, il, 1676-1687, h. h.

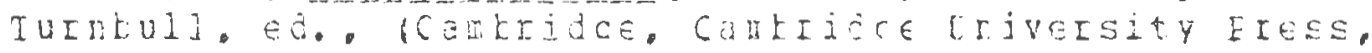
$1 \subseteq E(), F F \cdot 2 \beta E-C S$.

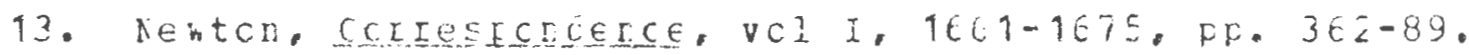

14. Itid, FE. 413-5.

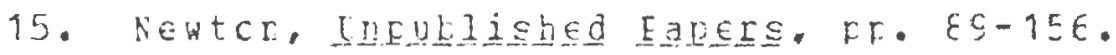

16. Ilid. Fr. $214-2 \varepsilon$.

17. Vektcn, CEticks, f, cxxiij.

18. Newtcr, Natheratical Erjpcinges, r. 547.

19. Nentcn, Ckticks. F. 349 .

2C. ThCondike, CE, Cit., VIII, F. 634.

21. liektcr, CEt icks, F. $\vdots \Sigma 2$. 
22. Schofieju, E. Yecheden a

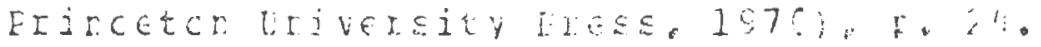

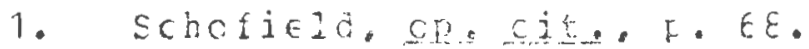

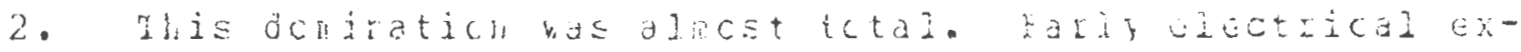
ferinenters readily acrechledaed theil debt to hite for

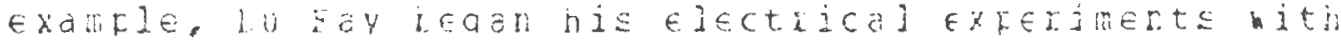
a IEfetiticr. cf Grayts holk. ett, this domilabice

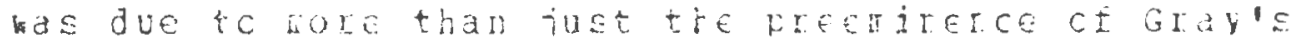
electrical Exferinerts, fcl it drfears that he activeIy disccurage corretiticre Ir a fetei to the ricyal

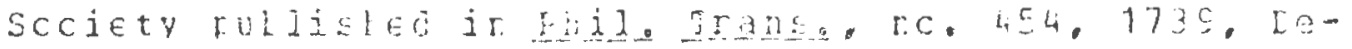
saquliers prefaces bis first ful]istec eccount cf his electidical experiarte ith a laerr bor the dojay in ccrmulicaticn to tre scciety blict slows this cuite clearly. I te excle qifer has tid [esayujers has

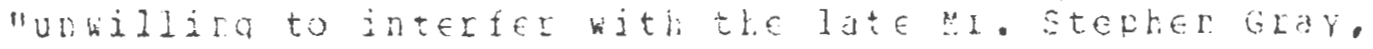

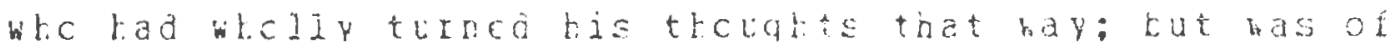
a terfer to que it intigely cuer, it le idaqued triat arytrirc kas teirg acre ir cFfojticr tchim."

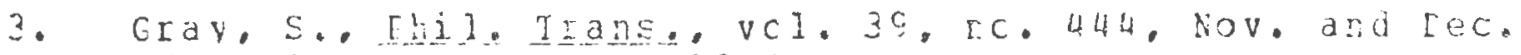
T73E. itEUVII, KE. U20-3.

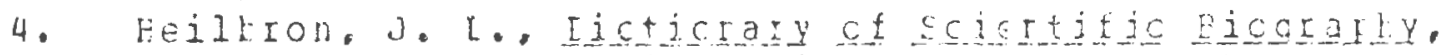

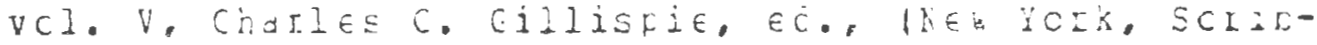
IEI, 1972), FF, 515-7.

5. Chifran. F. A... ISIS 45, FF. 33-40 1954).

E. Chifar., E. A., IEIS 49. FF. 41L-3: (1SEE).

7. Cohen. I. E.. ISIS 45. FF. 41-5C (ISE4).

3. Heiltror. che cit., r. 515.

G. Chifrar. 49. Kr. 42s-31.

10. CChEr, 45. F $.4 E-7$.

11. Chifat. 49, K. 422.

12. Chicitar. 45, F. 4 C.

13. Cober, 45, F. $4 E$. 
14. Chifian, 49, F, 424.

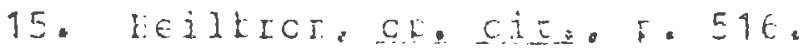

16. Cober. L5. Rp. 49-50.

17. Chifran, $5,5.34$.

18. Heiltron, cr. cit., F. 516.

19. Hauksee's viebs cn electideity cter a sharp certrast tc thcse ct Grap. These viens, as bell as an ac-

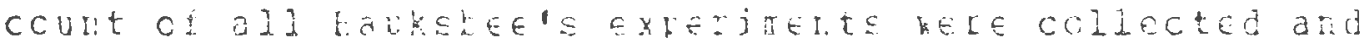

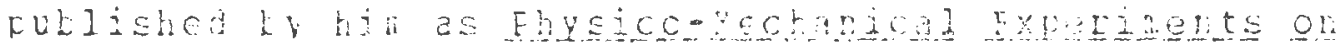
Varjcus spocts In the fietace, leurshes maxes it clear that tids study oz eiectricol ottraction ard zepulsion is coly a part ct the qereril la te cf attrac-

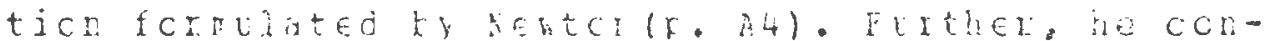
clujes that "the fffluva, rokever suraj scever they

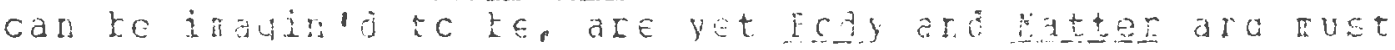

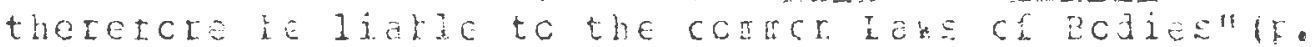
Et). Itis coeflectiar afrecact bas totaliy lifearat than that usad by Gay and cesciled ir the ensuira secticr. laukstee's etrjuvicn was clearly outside tho tradition ot eseentialisteliluvia, aro, ico this

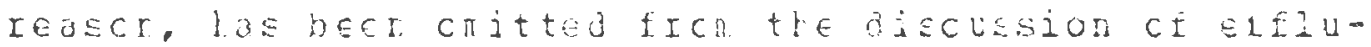
via in the early leth centurv.

\section{V}

1. Schcficlic, cp. Cit., F. Ė.

2. Cohen. I. E. Erorkir ard Nentcr, Ealtiacre, J. H. First $(C . .19 E(E), F, 36 \subseteq$.

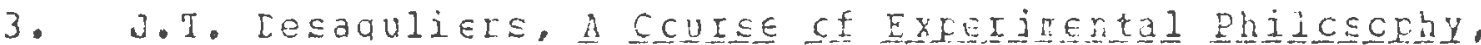

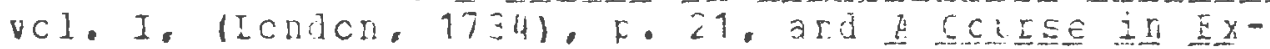

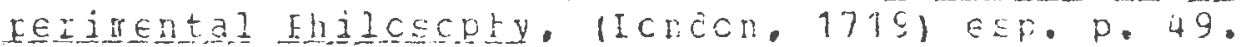

4. A. E. Fa]I, Eicticrary cI Scjeltific Ejcoraphy, vcl. IV. F. 44.

5. Lesaquiers' electrical rafers day le fcurd in A ccurse

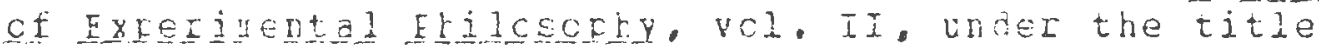
"A Lissertaticr cCnCErninG EleCtriciy, scitter is the

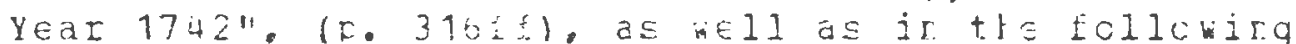
vcluats cf the Fhil. In Ins: VC1. 41, IC. $454, F F .1 E E-C \equiv$ 


\begin{tabular}{|c|c|c|c|c|}
\hline "1 & i. 11 & $n$ & F. & $; \subseteq z-c$ \\
\hline 1 & $", 11$ & $"$ & FF. & $2 \because 2$. \\
\hline$" 1$ & $"$. & 4 & HE. & $269-10$ \\
\hline 11 & $", " 1$ & 459 & $F E$. & $\epsilon 34=i$ \\
\hline$"$ & $" z " 11$ & $"$ & FF. & $f 37-c$ \\
\hline 11 & 11.11 & $"$ & FF. & $E 35-40$ \\
\hline 1 & ". " & $4 E 0$ & R. & $669-6$ \\
\hline " & 2,11 & 462 & FF。 & $14-1 F$ \\
\hline
\end{tabular}

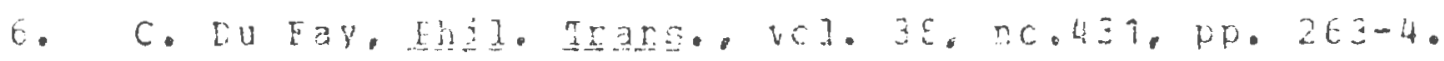

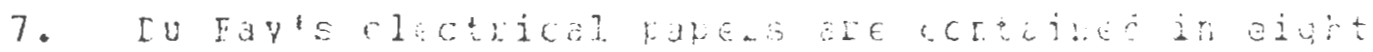

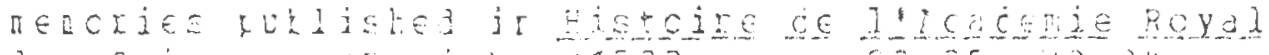

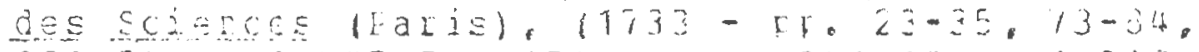

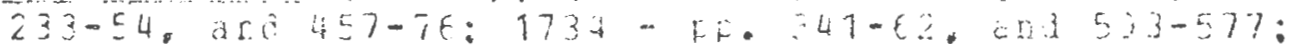

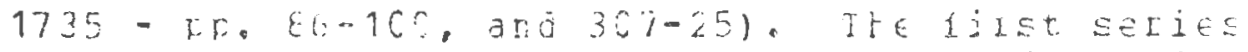

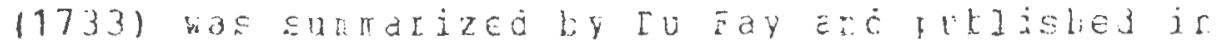

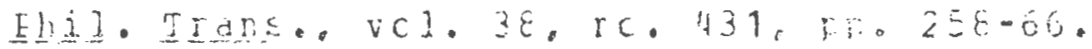

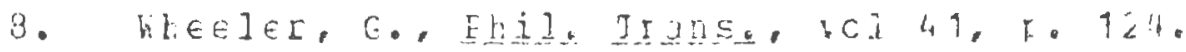

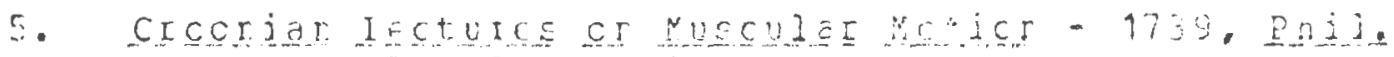
Iranse, UCI, 46, F. Xix.

10. IEjd, E. xxxvi. 
EDE 48

Dppendix I 
PACE 49

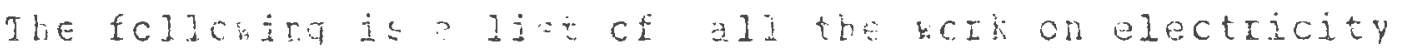
which sterher eray corrunicatid to the boyal scciety. Excert icr the firet ncrk, all these lettels werefurlished

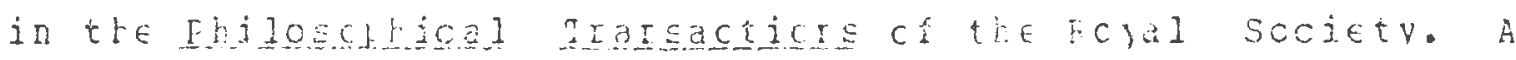
complete list cr cxay's fubistec borks is to be tound in I.

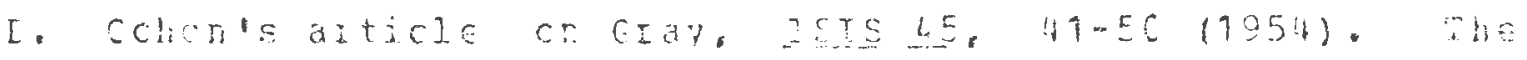

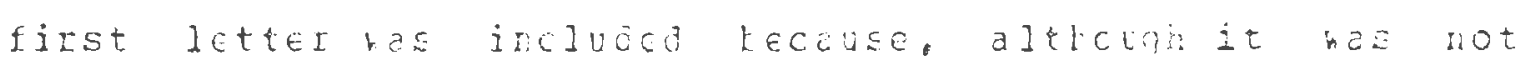
fullishea in Gra's lifetime, it was clearly intended to te s.

G1a. An Uneuldished letter of stebter cray cr Electrical Ex-

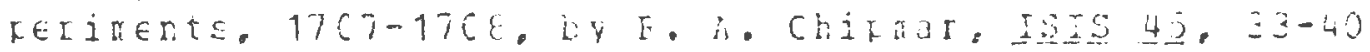
115541 .

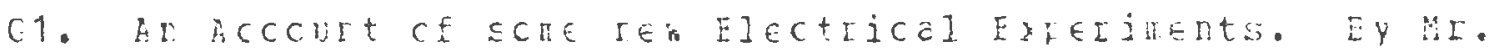

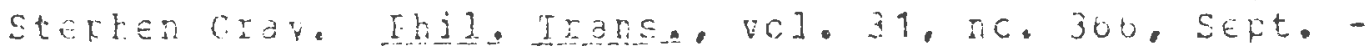
IEC. 1726 , ited i, raues $164-7$.

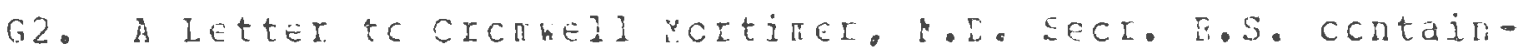
ind severa] Exferiments concerrirc flectricity; Ly ur.

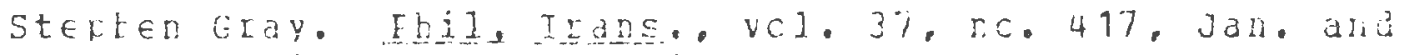
FEL. 1731, it $\in \mathrm{B}$ V. Fages $1 \varepsilon-44$.

63. A letter corcerrira the flectricity cf hater, irca Mr.

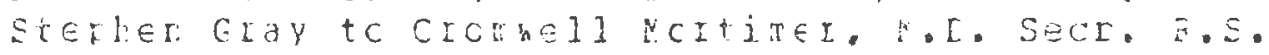
Ebil. Irars., vol. II. FaQEE $227-3 C$.

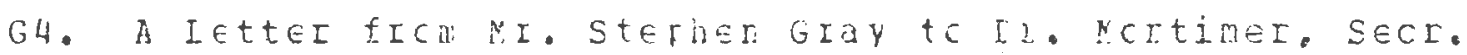
F.s. containing a tartier Acccurt ct ris Exreriaters ccrcerrita Iiectricity. Charter - fcuse, June 7 th.

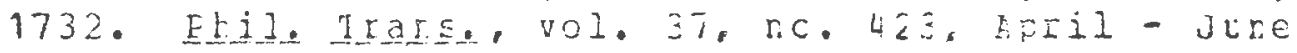
1732. iten IV. Faaes $235-\subseteq 1$.

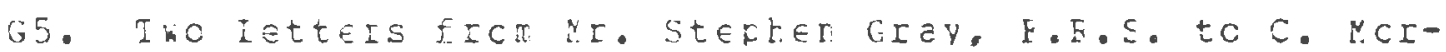
tiueI M. L. SECI. 5. S. CCrCeIninc farther Accounts cf his Exferiatents ccncerninc rlectricity. Ehil. Irass.. 


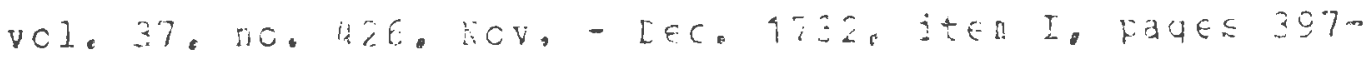
407.

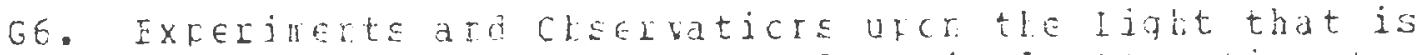
Froduced by corrunicatinc ilectrical Atracticn to ani-

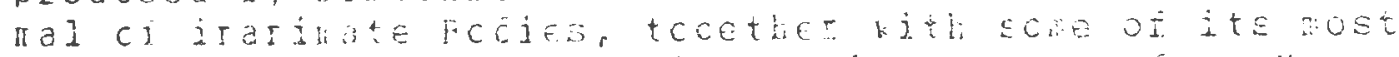

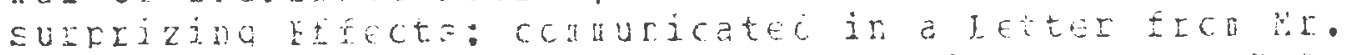

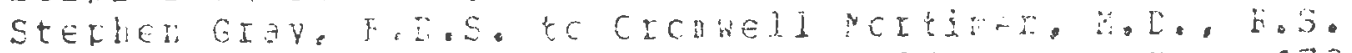

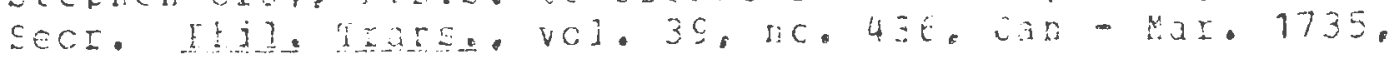
item V. rages $1 \xi-24$.

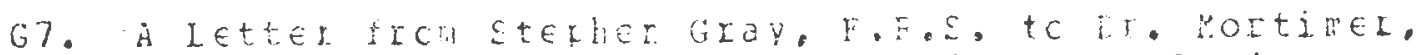

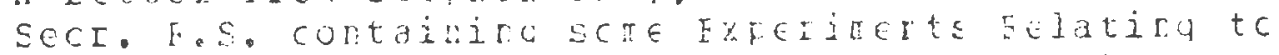

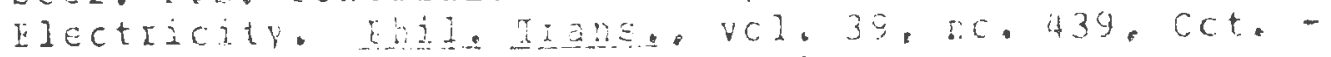

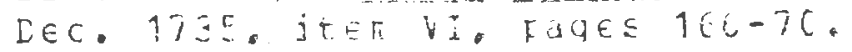

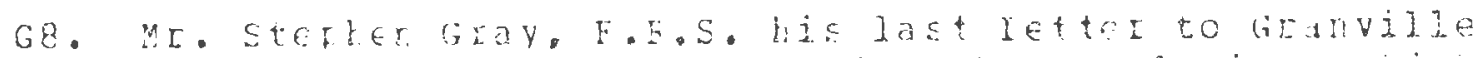

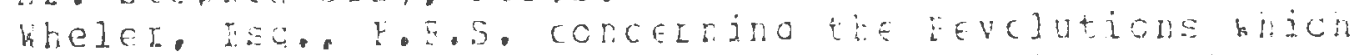

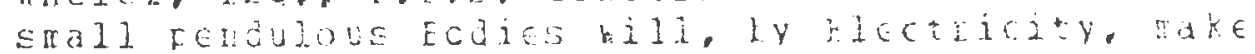
rcuro larcer cies fron hest tc Fast as Ilanets do rouna

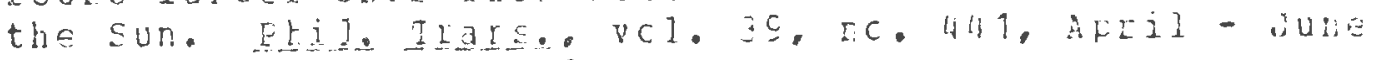
1735. iter Ii. Fäe 220 .

69. An Accernt cr scite Electrical Expoineris intended to be contuajcuted tc the FCyal secisty ly r. S. Steften

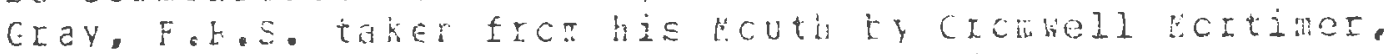

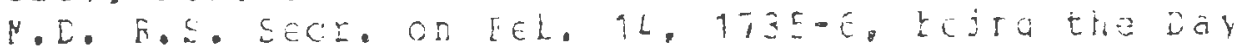

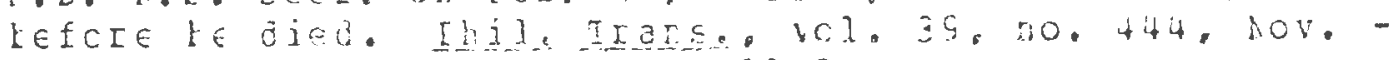
LEC. 17JE, its VIIZ, fades $450-3$. 
I. $G \in[\in[a]$

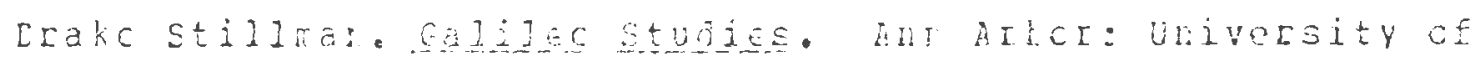
rictiade tres. 1575

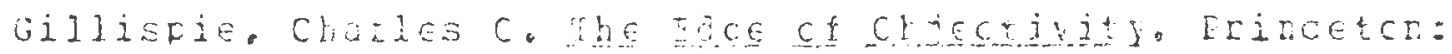
Erircetct lriversity ELESE, TSGT.

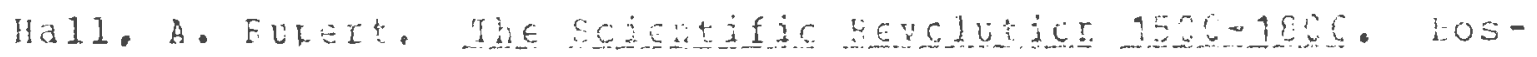
tCr: EEACCY PrESE, 1562 .

Hcltcr. Geiald. "in the tolo cf Jhenate ir Scientitio

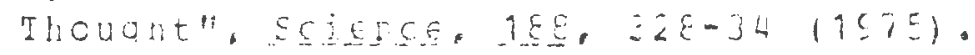

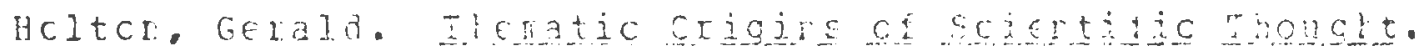

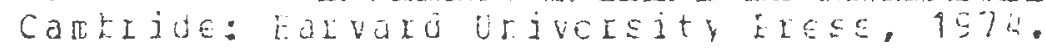

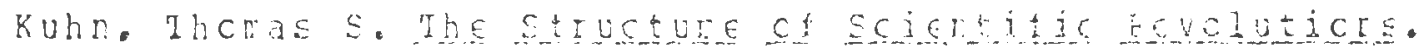
chicacc: triversily ct Cricadc lress, 1974.

Mertcr, folert K. "Thenetic sralysis it scifrce: Notes or

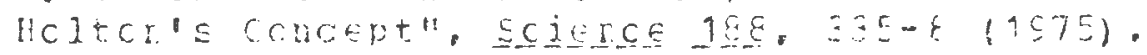

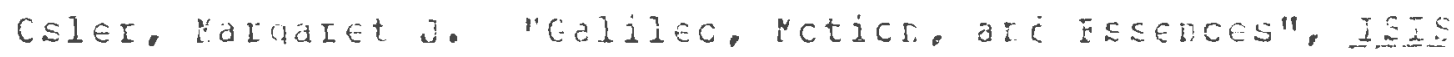
ㄴ․․ $564-5(1573)$.

Yates. Frarces A. Gicrdarc Erurc anc tre fergetic ara-

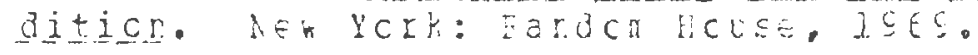

\section{ExjaIy Scuices}

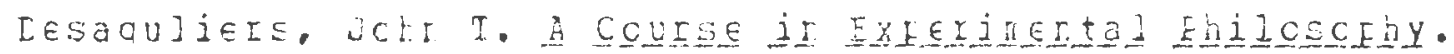
I c n $3 \mathrm{cn}, 1719$.

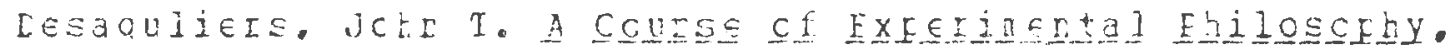

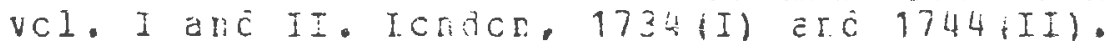

Desaquiers. Jchn I. "Some Thuchts anc Exferinents ccncernirq E] ectricity", Eis]. IraIS, vcl.41, no. 454, $186-93(1746-1)$.

Leşquliers, Jctr I. "Exrerigerts rade befcre the foyal

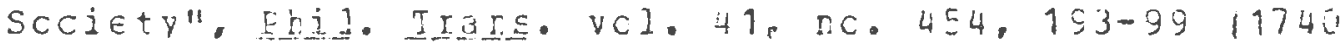
$-1)$.

Lesaquliers, Jchr I. "Ar. Accclrt cf scae electrical Experiaents rade lefcre the rcyal scojety cr. Inursiay the 


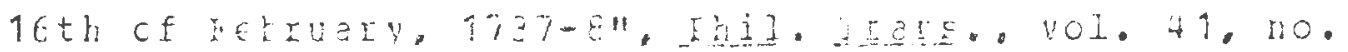
$454.2 C C=8,130-1)$

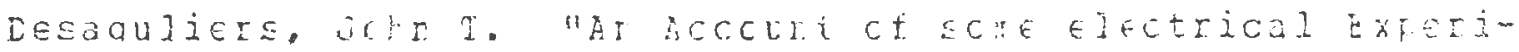
wade at lis fCyal bighese the trince ct rales's licuse

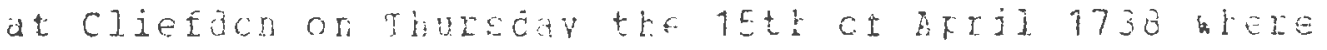

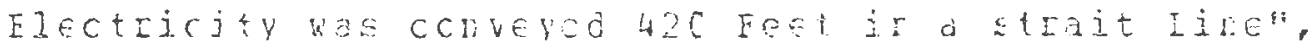

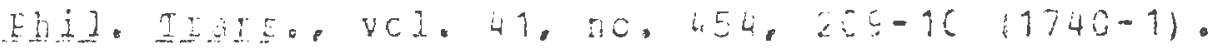

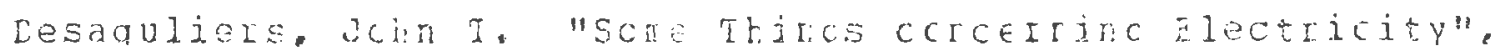

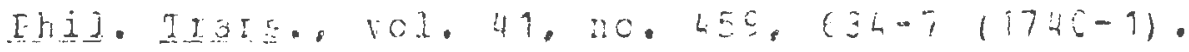

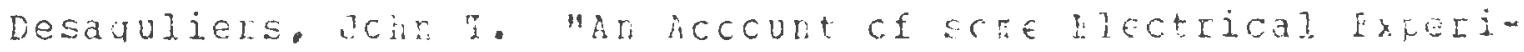

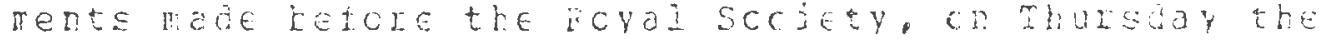

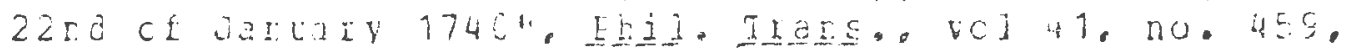
$E 37-c(174-1)$.

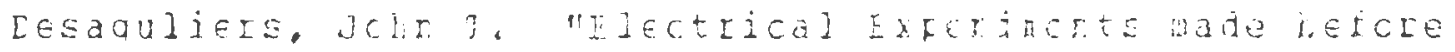

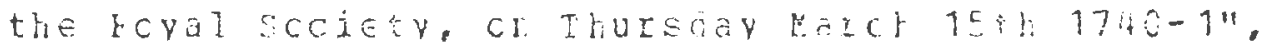

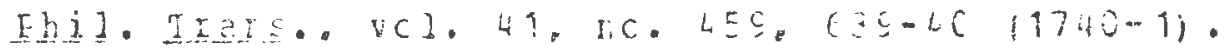

Lesaqujers, dChn I. "Several Ijectrjcal Ixferiante. nadi at variovs Tines, tetore the Ecyal Ecciety", Inil.

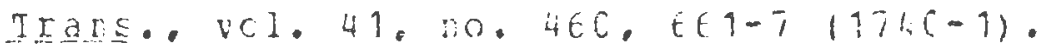

Lesaquiers. Jchn T. "Scae further Chservaticrs concern-

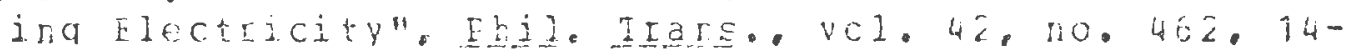
\& $(1742-3)$.

Iu Fay. Charles-irarccis, "A Ietet...tc his Grace charjes Luke ct richacro anc Lencx, ccrefride liectzicity". Fhil. IIars.. vol. $3 \varepsilon, n c, t 31,2 \varepsilon \varepsilon-E \in(1733-4)$.

Du Fay. Charlec-erancois. "reacire sur l'electeicite",

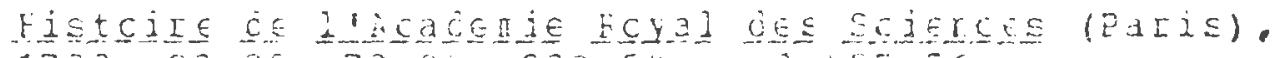
$1733,23-35,73-84,233-54$, and $457-76$.

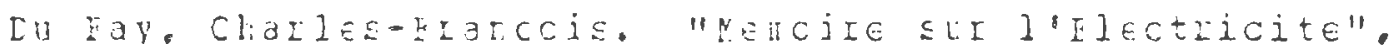
Listcire de I DC $1734,341-62$, ario $5(3-77$.

[u Eay, Charles-erancois. "ketojne sur l"ejectricite",

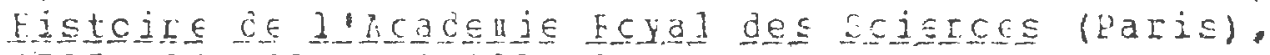
$1735.86-100$, and $307-25$.

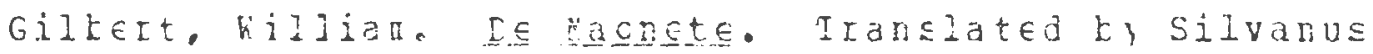

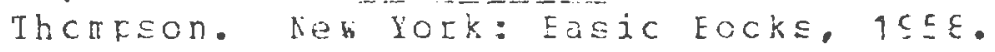

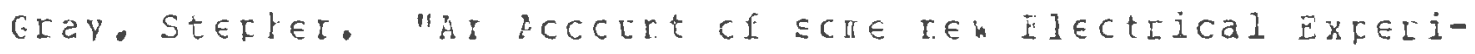

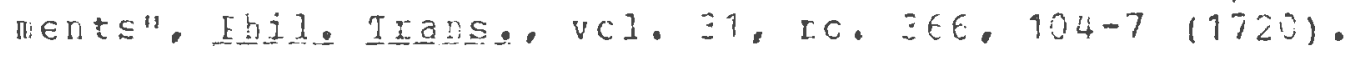

eray. Stefrer. "A Ietter te CrCbrell Mcrtiner. M. D. Eecr. 


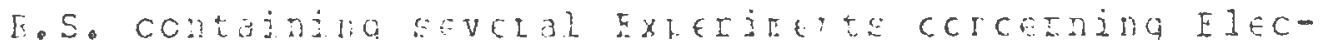

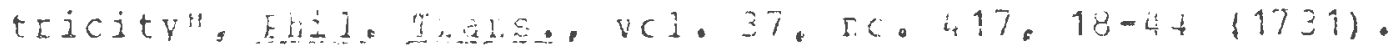

Grav, stefhen. "t letter concezrira tie telectricity ce

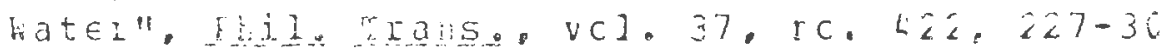

$(1722)$.

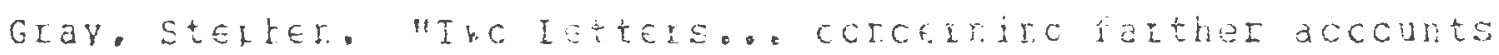

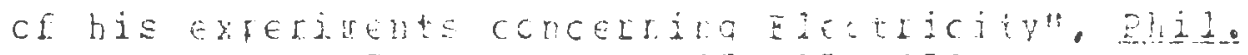

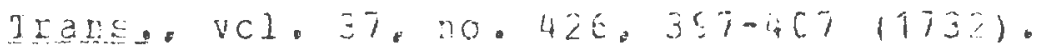

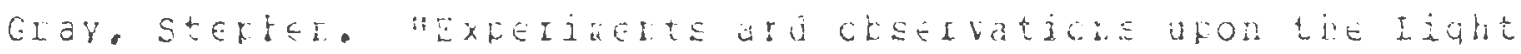
that is froduced ly coni vineatio ilectrical Bt-

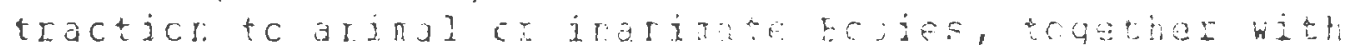

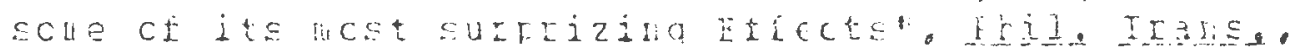
vCl. IE. nC. $4 \vdots E, 1 E-24$ 11725).

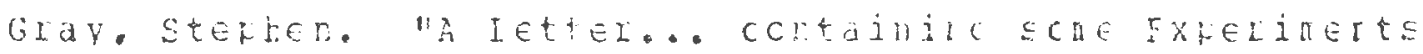
rclatirc tc Electriciti", Fl I. MaIs. vol. 39, no. 439. $166-7$ (17:5).

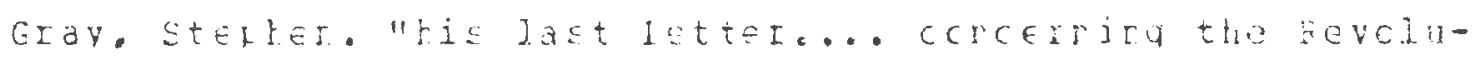

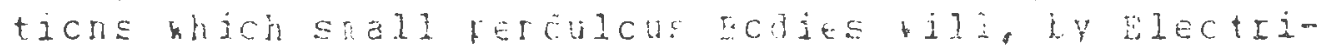

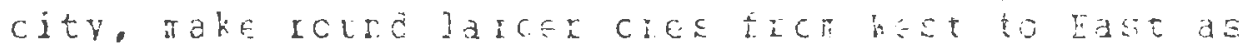

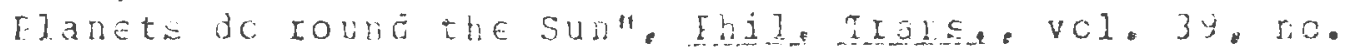
441. $220(1735)$

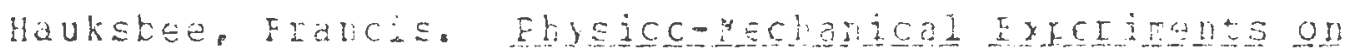

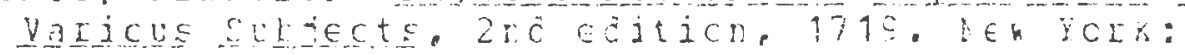
JChusCr EERILt CCIFCiaticn. 1970.

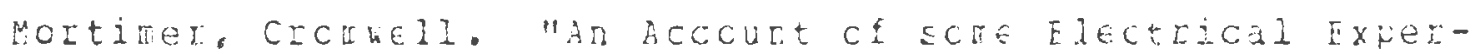

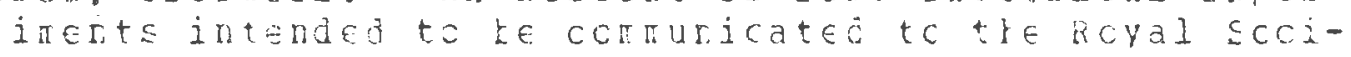
Ety kY KI. Stefher GIay, F. F.S., taker trom his touth

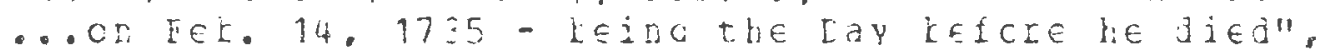

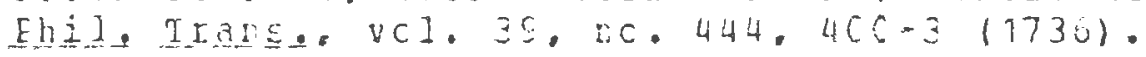

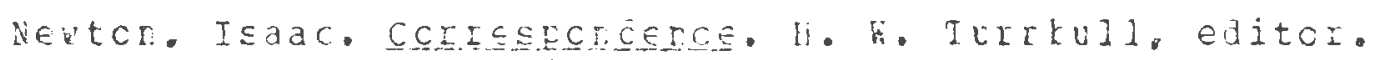
Cambidqe: CambIjdce University EIsss, 1CEC.

Newtcr. Isaace Ericiria vcl. I ard II. 172 c edition.

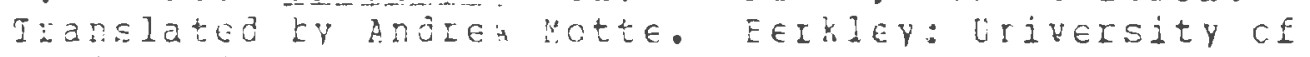
Califciria EIES

NentCD, Isaac. CEticks, 4th Editicr, 1730. Saw York: ICvor Eutlicaticrs, Ir.C. 1S52.

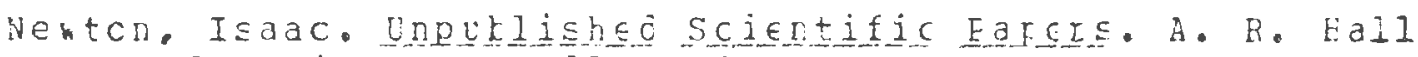
and Nate Ecas Fali, eujtcrs ard trarshatcrs. Carbriale: Carbiáce Uriversity Eress, 1sti. 
IIJ. Seccrary sources

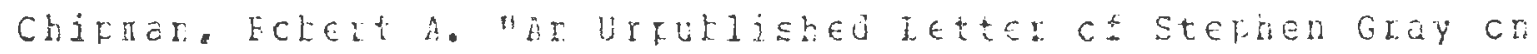

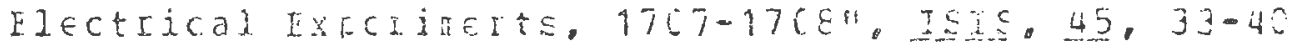
$(1 \subseteq 54)$

Chicuan. Fobert A. "Ine vonecrift zettere cf Stephen Gray.

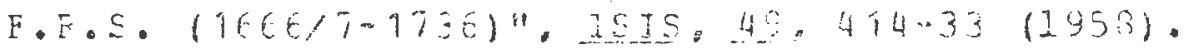

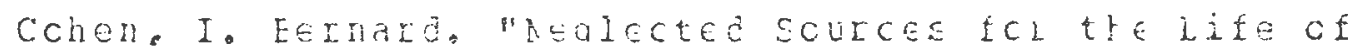

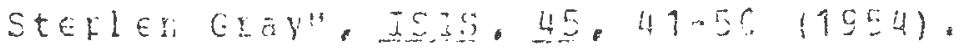

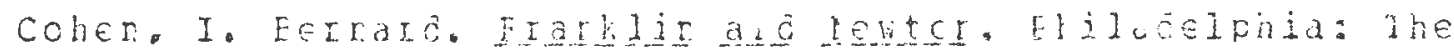

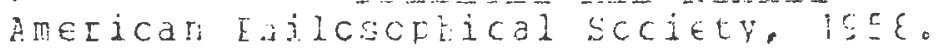

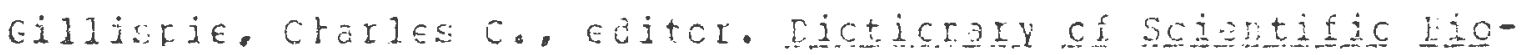
crafry. Aen york: scrituer. 10i:

Hall. Marie leos and Hall, A. Fufert. "Hetcr's Eectrical.

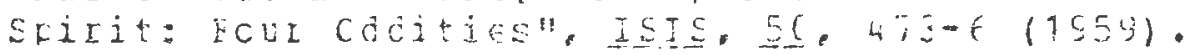

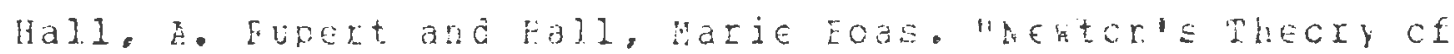
SatteI". IEIS. E. $131-44$ (196C)

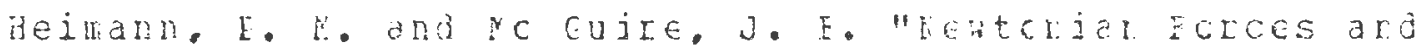
Lcckear Eckera: Ccrcerts cf nattor ir Eiqhteenth-Century Itouct:" fisterical ctucies ir t ts EnYSical Scierces. $3,253-\Xi 6 \in(1571)$.

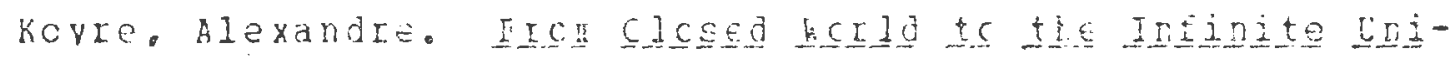
yerse. Eajtimore: Ire JChrs Hofkirs itess, $197 \mathrm{C}$.

Kcyze. Alexandre. Ieftorian stucies. Chicaqc: The university CA CricacC ELES

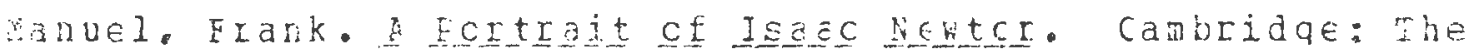
Earvard Criversity EIESS, 1508.

Sohofield, Robert F. yecronisf ard geteris]isa. Princetor: Erircetcr Lriversity ELss. $197 \mathrm{C}$.

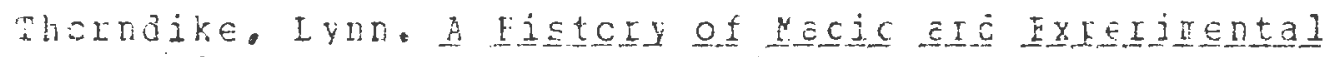
Scierce. New YCIK: iacililar CC.. 1525-58. 